\title{
THE REMOTE EFFECTS OF GUNSHOT WOUNDS OF THE HEAD.
}

\author{
Br L. BATHF RAWLING, LoNnox.
}

\author{
SYNOPSIS. \\ 1.--INTronectrorr. \\ 11.-SCal.p-Wounds. \\ III.-Non-PFnetrativg wozNIs. \\ IV.-PEnlitrating Wounios :- \\ a. With Hernia Ceribri. \\ b. With Foreign Bodies Retained in the Brain, \\ V.-Pehforating Wotents. \\ VI.-Fracturfon Base. \\ VII.-General Remarks on the Remote Fffects of Head-wovids, with \\ Special Rfference to Headache, Fits, etc. \\ VIII.-Dfcompression, with Details of 40 Cases. \\ IX.-Closure or Protecrion of Apertures in the Skill. \\ X.-Postsciniptum.
}

\section{INTRODUCTORY.}

Sufficient time has now elapsed since the Great War to justify expression of opinion as to the remote effects of gunshot wounds of the head, and other head-injuries of warfare. I have, at any rate, some justification for so doing, for, from 1914-20, I was in touch with this class of case (1st London General 1914-16 ; 34th (Welsh) General, India, 1916-18 ; 1st and 4th London Generals 1918-20 ; and from 1920 onwards, at the Ministry of Pensions Hospital, Ruskin Park).

Although service in India brought to my experience some new and interesting facts connected with gunshot wounds of the head, and malarial and heat-stroke cases with head complications, it was during the first six months of 1918 that I encountered the great mass of material which forms the basis of this paper. During that time I was in charge of 150 beds reserved for head cases at the 1st London General Hospital, together with another 100 at a convalescent home to which recovering cases were sent, and these 250 beds werc usually occupied by head cases of all sorts and of all grades of severity.

Stress of work, foreign service, and the general conditions prevailing, prevented me during the war from investigating the cases in the most desirable manner, but I have kept in touch with a considerable number of the men, many of whom write to me from time to time, and some of whom I see periodically. This paper is based on these cases, supplemented by observations carried out since, both at St. Bartholomew's and at the Pensions Hospital. At the latter hospital $I$ am in constant touch with patients suffering from head injuries, and the investigation of these cases, in the comparative leisure of peace-time, has enabled me to curb enthusiasm, to modify earlier ideas, and to concentrate on the more practical points.

During the winter of 1920 and onwards, being in possession of details of 1000 cases, I was desirous of obtaining facts from that number; but some had to be eliminated, 750 remaining. To these a form was despatched, requesting full information as to present condition, working capacity, etc. Replies were received from 452, from all parts of the world, the United Kingdom, ranch and town in Canada, Australia, New Zealand, Africa, and elsewhere. 
The results here tabulated may, thereforc, be regarded as representing the conclusions to which $I$ have come after no inconsiderable experience. I would add also that, to avoid any bias, I have not read the Report on Head Injuries, issued by the Research Society, preferring to come to my own conclusions, irrespective of the opinions of those distinguished neurologists and surgeons who, sitting together, issued that report. If my ideas differ from theirs, time will show which is the correct view.

The injuries in these 452 cases represented :--

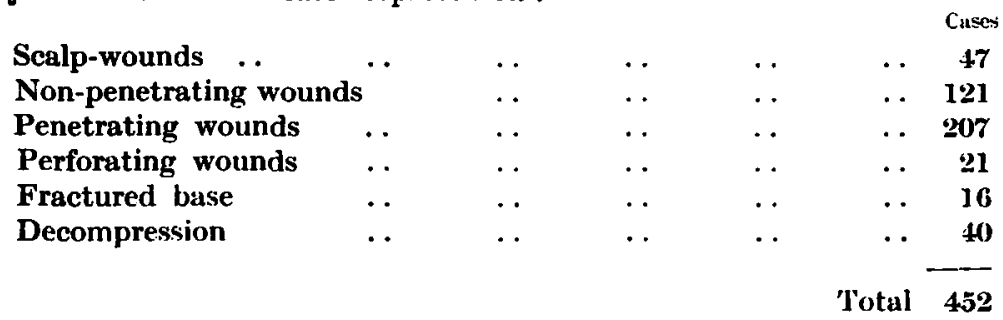

\section{SCALP-WOUNDS.}

Scalp-wounds are usually regarded as of trivial naturc-the bone is unbroken, and therefore the injury is of no serious import. Indeed, in comparision with the fearsome gunshot wounds of the head so frequently seen, the deduction seems fairly obvious. There is, however, another side to the picture, and the reports received from 47 cases of scalpwound, in their life-history up to six years subsequent to the reception of the injury, show that there is another aspect in the consideration of scalp-wounds.

In most of these 47 cases the injury was incurred during a "blowing-up' process, the patient often being ignorant as to what really happened. In the remainder, glancing shell-fragments had usually produced the wound.

An examination of record cards, and close scrutiny of the history, clearly show that in 22 cases (47 per cent) the injury was followed by a phase or syndrome which could be explained by no other hypothesis than that the patient was suffering from symptoms clearly pointing to definitc contusion or laceration of the brain, or to intracranial hæmorrhage. The facts in these 22 cases which give rise to this statement are as follows : In 12 cases the injury was followed by a period of constant and severe headache, often of so definite a character as to be the outstanding 'memory' of the case, the one thing that the patient remembers after all these years, and of which some are in dread of recurrence. These headaches were unquestionably due to a general increase of intracranial pressure, secondary to intracranial blood extravasation, with secondary cedema of the brain. This is confirmed by the statement in many record cards that lumbar puncture, frequently repeated, was carried out for the relief of the headache, in many cases with the withdrawal of blood-stained cerebrospinal Huid. In 6 cases the injury was followed by fits of the Jacksonian type, by localized paralyses, sensory disturbances, aphasia, etc., and in 5 of these cases the fits or paralyses persist at the present time. It is obvious, therefore, that the scalp-wound in these cases was complicated by a localized cerebral laceration or hæmorrhage. In 4 cases the injury was followed by a prolonged period of unconsciousness, accompanied by slowing of the pulse-rate, raising of the blood-pressure, vomiting, etc., all symptoms indicative of intracranial blood extravasation, with generalized cedema of the brain.

These 22 cases, all of which were $x$-rayed, with negative findings in respect to osseous injury, may be accepted as proof of the contention that intracranial complications werc present, the lesion being in each case of such a nature as to produce definite clinical signs and symptoms.

In the remaining 25 cases the reports were not so clear; but in view of the significant facts elucidated in the 22 cases, it is obvious that the after-history of these scalp-wound cases should be interesting, perhaps also offering a guide to the early treatment of such wounds in the future. 


\section{GUNSHOT WOUNDS OF THE HEAD}

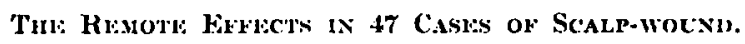

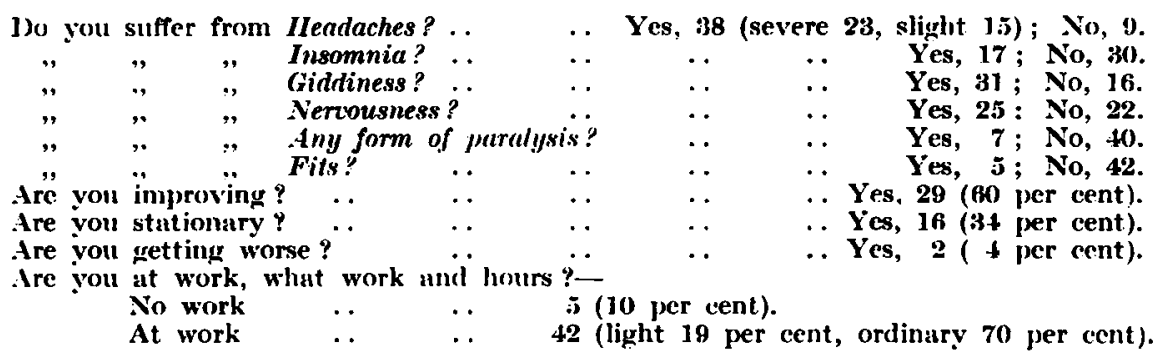

It scems to me that the outstanding feature in these cases is this--in spite of the fact that 81 per cent complain of headaches, 66 per cent of giddiness, 53 per cent of nervousness, 15 per cent of paralysis, 10 per cent of fits, yet 89 per cent are working. It must be concluded, I think, looking at the question from the broad point of view of presentday psychology, that the symptoms of which the patients complain, apart from fits and paralyses, must be of the minor type.

Nevertheless there remain the 10 per cent incapacited from work by reason of fits and palsies, and by severe and persistent headaches. It is probable that some of these would have benefited by early active treatment. Anyhow, it is about time that the expression 'only a scalp-wound' was forgotten, and that every case was treated on its own merits-with a clear basic understanding that the great majority of scalp-wounds of war time are associated with some degree of concussional cerebral change, amounting in many cases to cerebral laceration and contusion. intracranial hæmorrhages, etc.

Hvery case, therefore, demands the most careful investigation, with spccial reference to the prolongation of unconsciousness, pulse-rate, blood-pressure, persistence of headache, etc. Apart from bencfit that might accrue by early operative treatment in selected cases, all cases require prolonged rest and convalescence, and many of these patients must be regarded as totally unfit for further active service.

In confirmation of these statements I would draw attention to a paper in Bruin, vol. xlii, by Geoffrey Jefferson, on the neurological findings in 54 cases of scalp-wound. These cases were seen and treated at a Base Hospital in France and * in only five were no such evidences present". There were eleven definite local contusions of the motor cortex.

Jefferson's statements as to the carlier conditions, and my findings as to remote effects, are significant.

\section{NON-PENETRATING WOUNDS: DURA MATER NOT PENETRATED.}

This section refers to various fractures of the skull, many complicated by the presence of hamorrhages and brain injury, but all having an intact dura mater.

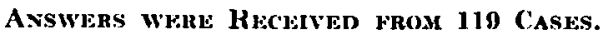

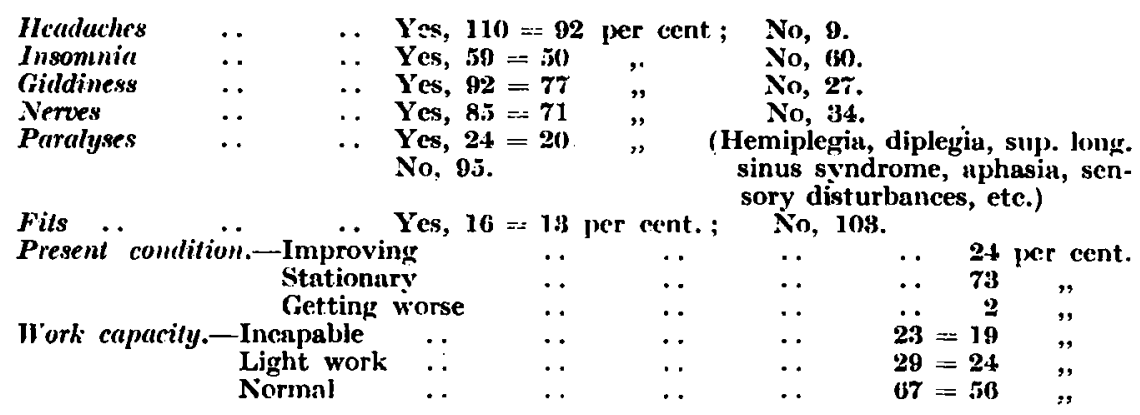




\section{PEnetrating wounds.}

\section{a. With Hernia Cerebri. b. With Retention of Foreign Bodies.}

Requests for information were sent to 206 cases of penetrating wounds of the head.

I possessed, as in all other cases referred to in this paper, brief but moderately accurate notes as to the nature of the initial lesion, and the operative findings. This series of 206 cases includes 35 where a hernia cerebri developed soon after the injury, 42 in which foreign bodies remained in the brain substance too deep for attempts at removal, 19 with extensive extra- or subdural hæmorrhage (due to sinus injury, middle meningeal hamorrhage, cerebral laceration), and many others in which foreign bodies had been removed from the brain.

The serious nature of some of these cases may be demonstrated by a few examples :-

Case 1.-Penetration of parietal region, shrapnel bullet retained in the very centre of the brain. Now suffering from slight headaches, nervousness, and some anæesthesia, but doing light work.

Case 2.- Penetrating wound of frontal region, followed by gas gangrene. Now well, except for occasional slight attacks of epilepsy.

Case 3.-Penetration of frontal region, followed by hernia cerebri, and abscess of the brain. Foreign body remains deep in the buse of the lobe. Well, except for occasional slight seizures.

Case 4.--Penetration of parietsl region, bullet removed from brain, followed by maggot infection of brain. Now working as a tram conductor.

Requests for information elicited the following replies :-

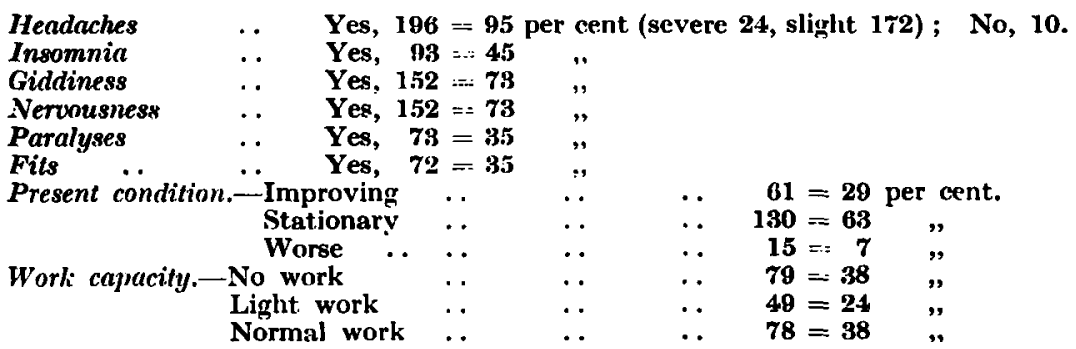

On analyzing further the 79 cases incapablc of work in regard to the nature of their original injury, it was found that:-

20 had suffered from hernia cerebri ;

10 had foreign bodies in various parts of the brain ;

3 had suffered from extensive abscess formation of the brain ;

5 had suffered from extensive intra- or extradural hemorrhage;

and, on going further into the actual cause which, at the present time, incapacitates them from work, the evidence showed that :-

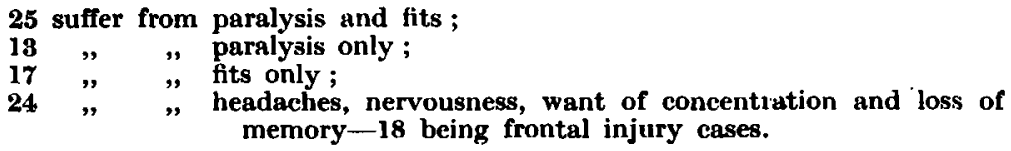

I might add that: (1) In addition to the 35 cases of hernia cerehri, 22 other cases of hernia cerebri died in hospital--57 cases in all, with a mortality of 39 per cent; and (2) In addition to the 42 cases with foreign bodies retained who recovered, 19 others died in hospital, all from spreading infection of the brain and meninges-mortality 31 per cent.

(It should be noted, therefore, that a death-rate from hernia cerebri of 39 per cent, and from retention of foreign bodies, with subsequent spreading infection of the brain, of 31 per cent, in base hospital at home, should be added to the death-rate from these two conditions as occurring in hospitals in France, etc.)

The table appearing at the end of Section VI, demonstrating the remote effects in relation to the severity of the lesion, shows clearly that penetrating wounds with hernia cerebri head the list-the most severe after-effects and the least work capacity. 


\section{GUNSHOT WOUNDS OF THE HEAD}

\section{v. PERforating WOUNDS.}

Inquiries from 19 cases brought the following replies:-

$$
\begin{aligned}
& \begin{array}{llll}
\text { Headaches .. } & \ldots & \ldots & \text { Yes, } 17=89 \text { per cent ; No, } 2 . \\
\text { Insomnia .. } & \ldots & \ldots & \text { Yes, } 10=53 \quad \text {, }
\end{array} \\
& \text { Giddiness } \quad \ldots \quad \text {. } \quad \ldots \quad, 15=79 \quad,
\end{aligned}
$$

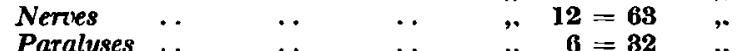

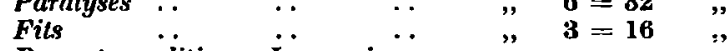

$$
\begin{aligned}
& \text { Present condition.- Improving } \quad . " \quad \ldots \quad \quad \ldots \quad 4=21 \text { per cent. }
\end{aligned}
$$

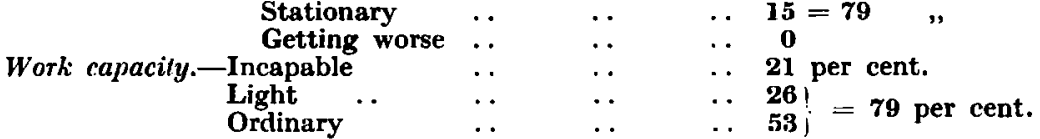

These 19 perforating wounds of the head were of all varieties and directions, anteroposterior, lateral, and oblique, but in no case was there any retained metallic or osseous fragment, all foreign bodies had passed through or had been removed, nor were there any cases of hernia cerebri. In some it was to be concluded that there had been ventricular involvement.

It is rather astounding to note that the general after-result of this, the most extensive and serious injury of the head which is compatible with life, is followed by such, relatively, satisfactory results. Headaches were less _severe, and--with the exception of two cases - paralyses and fits less evident than in penetrating wounds.

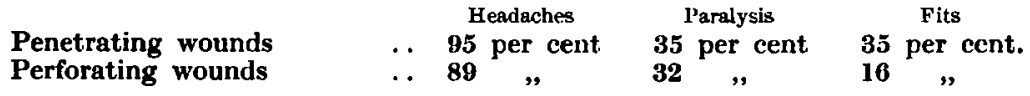

Furthermore, the work capacity of these perforating cases was of a high order.

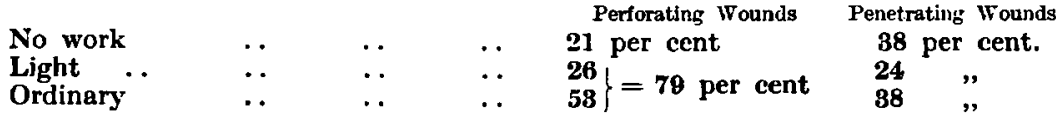

It should be noted also that 21 per cent perforating cases stated that they were improving, 79 per cent remaining stationary, and that in no case were the conditions getting worse.

\section{FRACTURED BASE.}

Fourteen cases of fracture of the base of the skull were admitted under my care. They presented no special features, but were similar in all respects to those fractured-base cases that are seen in ordinary civil practice. As a rule they had been transferred to England soon after the injury, and on admission were suffering from headaches, mental sluggishness, ocular palsies, facial paralysis, monoplegia, aphasia, etc. Obviously, as in cases seen in ordinary hospital life, the basal fracture was of itself of little importance, the issue being dependent on the extent of associated intracranial injury. All these cases

\begin{tabular}{|c|c|c|c|c|c|c|}
\hline Headaches & $\cdots$ & $\cdots$ & $\cdots$ & $\cdots$ & \multicolumn{2}{|c|}{$12=85$ per cent. } \\
\hline Insomnia & .. & $\ldots$ & $\ldots$ & $\ldots$ & $9=64$ &, \\
\hline Giddiness & . & . & .. & . & $13=93$ & $"$ \\
\hline Nervousness & . & . & . & . & $10=71$ & $"$ \\
\hline Paralyses & .. & $\ldots$ & $\cdots$ & . & $3==21$ & , \\
\hline Fits $\ldots \quad \ldots$ & $\ldots$ & . & . & . & $2=14$ & $"$ \\
\hline Present condition.- & -Improving & . & .. & . & $3=21$ & $"$ \\
\hline & Stationary & . & $\cdots$ & $\cdots$ & $10=71$ & $"$ \\
\hline & Getting worse & & $\cdots$ & $\cdots$ & $1=7$ & ", \\
\hline Work capacily.-I & ncapable & .. & .. & .. & $2=14$ & " \\
\hline & ight $\ldots$ & $\cdots$ & $\cdots$ & . & $5=36$ & ", \\
\hline & rdinary & $\cdots$ & $\cdots$ & .. & $7=50$ & :• \\
\hline
\end{tabular}
recovered, three or four after prolonged convalescence. No operations were performed on these cases other than occasional lumbar puncture for the attempted relief of the more severe grades of headache. In this late-history, the following results were obtained :-

vol. $\mathrm{x},-$ NO. 37 . 


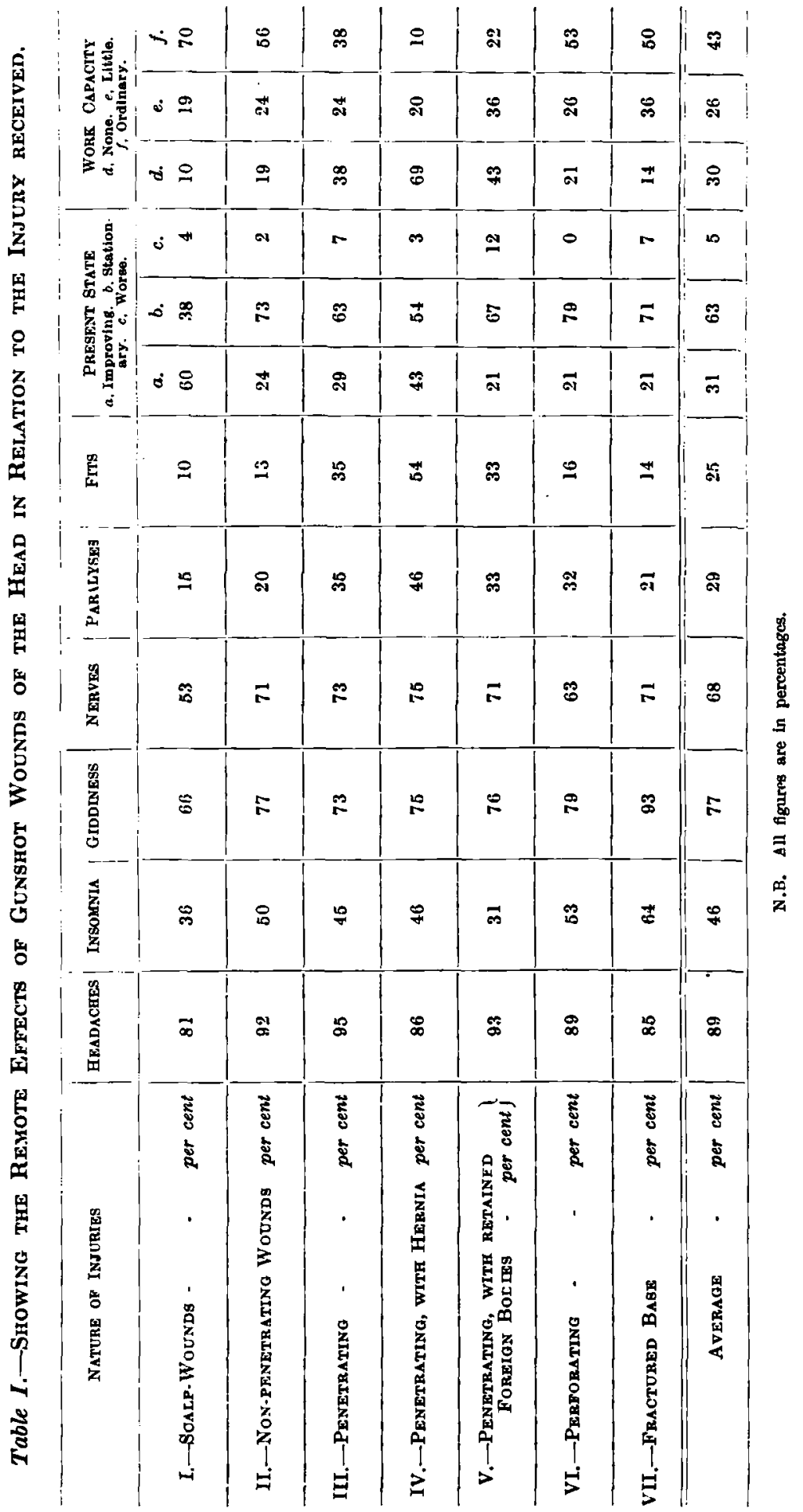


VII. GENERAL REMARKS ON THE REMOTE EFFECTS OF GUNSHOT WOUNDS

OF THE HEAD, AND OTHER HEAD INJURIES: WITH SPECIAL REFERENCE TO heAdaches, fits, Retained fOREIGN Bodies, Palsies, etC.

" In addition to those fearful headaches from which $I$ suffered, but which are now much better as the result of your operation, I get terribly nervous when going aloout the streets. I'm always thinking I'm going to see someone knocked down by a car. The noise of backfiring of a car or cycle has a very bad effect on me. On such occasion my legs refuse to carry me, my knees go away from me. Concentration I find difficult, and in many cases impossible. Reading, except light stuff, is impossible. I've some terribly violent fits of temper, arising from trivial things, I find difficulty in controlling myself and lose control at most unexpected times. I sometimes have the feeling that I am going unconscious. Several people have thought at times that I was drunk. I'm T.T. I'm living a quiet life, and trying hard to fight above complaints."

This letter, one of the replies received to my inquiries, is typical of many others. It is so vivid a description of the general after-effects of a gunshot wound of the head that it is utilized as a text to this section.

Although the headaches are so frequently the outstanding, predominating feature in the case, it is quite clear that they are merely part of a more generalized state, one feature of a syndrome. I have dealt with this question in two previous publications, ${ }^{1}$ and propose merely to recapitulate a few points.

In the syndrome are included the following conditions : (1) Headaches; (2) Giddiness ; (3) Insomnia ; (4) Mental anxiety, depression, irritability of temper, and ready fits of violent passion; (5) General tremulous condition, shaking hands and uncertain gait; (6) Slight exaggeration of knee-jerks, with spurious ankle-clonus; (7) Fits ('fainting', epileptiform, and epileptic).

Since these symptoms occur with such frequency after gunshot wounds of the head, it is fair to argue that they all have some common cause, and I purpose trying to prove that, in many cases, at any rate, they are associated with, and dependent on, a generalized condition of cerebral oedema. This statement is obviously not final and conclusive; but it can be proved, at any rate $(a)$ that in most cases there is a great excess of cerebrospinal fluid, and $(b)$ that the removal and drainage of the excess brings about, almost instantaneously, a great relief of all symptoms.

It is necessary to take the most obvious symptom, headache, as a guide, noting carefully the presence or absence of excess fluid in those more severe cases that come to operation, observing the immediate results obtained, but withholding final judgement till such time shall have elapsed as will justify one in coming to more or less final conclusions. This is the course that I have adopted. The second of the two earlier publications on the subject was published in April, 1919, and three years have elapsed, or nearly so. The theories there advanced have received ample confirmation, not only from other cases of gunshot wound of the head, but also from many cases of civil practice, and from reports on cases operated on by other surgeons. Operation was only advised, and carried out, when my hand was forced, in the worst type of case-in those patients who were 'fed-up', wearied with the incessant pain. In those earlier papers I was cautious in my prognosis ; I was uncertain whether the great and immediate benefits would be maintained. Sufficient time has elapsed to enable more definite statement. The late results are here published of 40 cases of subtemporal decompression, where this operation was advised and conducted with the main object of headache relief. These cases are described and scheduled later. The results, taking them as a whole, are satisfactory.

\section{HEADACHE.}

By reason of its frequency of occurrence, its intensity and severity, its incapacitating effect on the patient, as also by its pathology and relief on decompression, headache forms perhaps the most interesting of the remote effects of head injuries, whether gunshot wounds or civil injuries. At the present time, four to eight years after the injury, 88 per cent of the cases from whom replies were received still suffer from headaches, varying 
from slight and inconstant to severe and incessant, with, in these worst cases, periods of utter prostration, completely incapacitating them from work and rendering their lives miserable. The maximum percentage of headache was seen in penetrating wounds of the head, 95 per cent, the slightest degrees in cases of scalp-wound only, 81 per cent. Thus, by reason of the frequency and severity of headache, it is obvious that no apology is needed in considering the question fully.

In the great majority of cases the headaches date from the time of the original injury, and some patients still shudder at the horrible headaches they suffered from after regaining consciousness. Indeed, in many cases, the fact is noted in the history-card, and lumbar puncture was frequently carried out for its relief. The average after-history of these cases runs somewhat as follows: some weeks or months later, the headaches diminished in intensity and frequency, either finally reaching the slight and inconstant stage, so frequently observed at the present time, or showing little or no amelioration, remaining constant and severe.

In some, the earlier remission has been followed, during the last year or so, by a return to the earlier conditions, by relapse and exacerbation, often as the result of a return to work under the present difficult trade condition. Doubtless, family considerations, with attendant anxiety, have tended to add to the conditions aiding relapse. In others, after two or three years of comparative remission, the headaches have returned, sometimes in a severe form.

As seen at the present day, the patients suffering from the more severe grades of headache present a very typical facial appearance. It is easy to diagnose the condition as soon as the patient is seen-dour expression, fixed features, seldom relaxing and relapsing into smiles or more cheery expression, features outwardly expressive of headache-eyes of pain, with lids half-closed, frowning-the typical appearance of one suffering from headache. They are little interested in their surroundings, only too eager to accept any suggestion of operative treatment, with the hope of finding some relief from their condition. "I don't care if you cut my head off" is a common reply to suggestion as to operation. The life is utterly miserable, and a conversation with the wife or sister is quite enough to clinch the argument as to whether operation is justifiable or not.

Many of these patients are soaked in bromides, etc., and their depressed state must be considered in that light. A period of remission from narcotics should be advised and carried out previous to final conclusions. I wish to urge, and point out, that operation should be considered only when all other measures fail. That has been my custom, otherwise I would have reported on 400 cases of subtemporal decompression instead of 40 .

In the majority of cases the headaches are localized to the frontal region, sometimes to the occipital, more rarely to the vertex, with now and again a definite indication as to the localization of the pains to the region injured. Sometimes the pains are temporal or bi-temporal in position. Usually, however, "behind the eyes" is the complaint- " my eyes feel as if they were bursting".

In regard to the time of onset, provided that the pains were inconstant, the headaches were most marked early in the morning, on waking. The next most frequent time of occurrence was about 5 o'clock. In all cases the headaches were intensified by exertion, bus rides, cinematographs, etc. Family rows were exceedingly conducive to further trouble. In the more severe attacks the patients retired to their rooms or their beds, only demanding quiet-curled up in bed, in the typical condition of cerebral irritation. Such cases were only too eager to be taken into hospital where they could be away from the noises of the house, rampageous children, etc.

In some cases the headaches are of a 'cyclic' character, recurring every two or three days, perhaps with a week's remission; comparative freedom, and then the attack, then freedom again till the next bout.

In relation to atmospheric and climatic surroundings these patients are regular 'barometers'. A ward visit on a dull and heavy day with marked humidity, shows that almost every head-case has a headache, the more serious cases being miserable in bed. 


\section{GUNSHOT WOUNDS OF THE HEAD}

On a bright and clear day, especially in the cool weather of spring and winter, the conditions are reversed, all are comparatively bright and smiling.

Stuffy rooms, engineering workshops, with their noises and clangings, are bad for these patients. Open-air life, with light work, is markedly beneficial.

The prostrating attacks are often accompanied by a slight rise of temperature, $99^{\circ}-100^{\circ}$, with moderate degree of rise in blood-pressure, combined with some slowing of the pulse-rate. Marked distaste for food, with some nausea but no vomiting, and insomnia, accompany the attack.

The discs rarely show any definite changes, amounting in the more severe cases to some engorgement of the retinal veins. I have yet to meet a case with true papillodema.

In some cases the headaches are associated with an outburst of fits, usually of the epileptiform type, and it is remarkable that in some cases where there is a definite association of headaches and fits, the headaches very definitely lead up to the 'fit' development - the headaches gradually get worse till "my head seems as if it were bursting", then comes the fit. And so on, till the next occurrence.

Now, as to the causation of these headaches. In the first paper published on this question, in 1918, it was stated that they were dependent on an increase of intracranial pressure, and that the increase of pressure was due, in the great majority of cases, to an excess of cerebrospinal fluid, the general sodden appearance of the brain and meninges giving rise to the term applied to the condition in general-cerebral oedema. This statement is proved by the two following facts : $(a)$ The presence of excess fluid as found at operation; (b) The immediate relief produced by the operation-lessening of the intradural pressure in subtemporal decompression, and the provision of a door for the escape of excess fluid.

a. At the operation of subtemporal decompression, the routine operation carried out for the conditions present, the appearances of the brain are absolutely typical-the dura mater, when incised, allows of the immediate escape of excess cerebrospinal fluid, sometimes spurting out at high pressure in the form of a jet. When the dura mater is more extensively incised, the brain appears water-logged by excess fluid over the whole of the brain surface exposed, most marked in the line of the vessels as they run in their sulci. These vessels would appear, by reason of this fluid surrounding them, as white odematous streaks. The fluid is seen to be exuding freely through the arachnoid, as drops or tears, these running together in rivulets, these again coalescing, forming a pool at the lower angle of the wound, trickling away on the towels. On gentle pressure with gauze over the surface of brain exposed, the excess fluid in the subarachnoid space is squeezed aside, and, on the removal of the pressure, reaccumulates rapidly-altogether a very definite and typical picture, a very wet sponge. The removal of bone in a subtemporal decompression is so planned that it is easy to insinuate a broad spatula beneath the temporo-sphenoidal lobe, and when this is done the great accumulation of excess fluid at the base of the brain is well demonstrated-lifting up the brain, and then allowing it to fall back again, each such manceuvre being followed by the escape and evacuation of considerable excess cerebrospinal fluid.

There can be no question, therefore, that, in the majority of cases, there is a great excess of fluid.

b. When such excess is found at operation, the immediate results of decompression and drainage are exceedingly good. If the operation is conducted under local anæsthesia, and the patient is not too doped to be capable of recognizing conditions and surroundings, he will express himself, at the termination of the operation, as free from the old headache, and on one or two occasions, the patients have sat up on the operation table and expressed themselves in terms of great gratitude. In any case, when seen the day after operation, the answer to inquiry is nearly always the same-the 'old' headache has quite gone, even though it may have existed for one or more years. I am using the term 'old' headache advisedly, because the patient when questioned as to his condition will nearly always say that he has a headache - this, on close questioning, is referred to the site of the wound. The decompression involves a fairly sensitive area and includes some section of the 
temporal muscle-in consequence there is often some degree of local pain and discomfort. It is necessary, therefore, to discriminate between the 'old' and the 'new' headaches. The 'new' headache gradually lessens, and in the course of a week or ten days it also goes.

The effert on the patient generally is equally marked-previously dour and depressed, now bright and cheerful, hopeful for the future, dreading the possibility of return of those old and fearsome headaches, hopeful of having cast aside for ever the gloom that previously enveloped him, thankful for the relief given. All this shows that the evacuation of the excess fluid, by decompression and opening of the dural compartment, allows of the immediate relief of the headache.

Confirmation of these facts is gained by a study of the minority cases, operation being conducted in the anticipation that one is dealing with a case of cerebral cedema, but in which, at the operation, little or no cedema is found, and in place of this a slightly weeping, or dry, brain with bulging of the brain into the wound. These cases do not do so well-the headache relief is more problematical, both immediate and permanent. These minority cases obviously come under a different category, and are of a different pathological nature-I think they are examples of ventricular distention, due possibly to chronic meningeal thickening at the base of the brain, interfering with the outward passage of the cerebrospinal fluid.

There is, so far as my experience goes, no definite method of determining which condition is present, cerebral œdema or ventricular distention. The symptoms in the two cases are practically identical. It may be argued that preliminary lumbar puncture would settle the question, but it does not, for in many cases of cerebral cedema lumbar puncture has been negative to cerebrospinal fluid excess. There is no absolute necessity for intracranial excess fluid to be accompanied by spinal excess-it all depends on the conditions in the region of the foramen magnum-whether the communication between the intraand extracranial systems is free or not. Details as to lumbar puncture in relation to treatment will be considered later.

It is necessary now to consider the origin of this excess fluid. Here difficulties begin. I have argued that as the fluid is chemically, cytologically, and pathologically normal in every respect, that there are only two ways in which to explain the excess : Either it is formed in excessive quantity and absorbed at an insufficient rate, or it is secreted at the normal rate and absorbed inefficiently.

It is not difficult to determine which hypothesis is more probable. It is only necessary to consider the physiology of cerebrospinal fluid, its origin and course, to advance what is, at any rate, a very plausible theory. It is accepted $(a)$ that the fluid is secreted from the choroid plexuses and lining ependyma of the lateral, third, and fourth ventricles, $(b)$ that the greater quantity passes up over the surface of the cerebrum, in the subarachnoid space, and $(c)$ that it is absorbed at the same rate as it is formed, into the superficial veins of the brain and into the lateral lacunæ of the superior longitudinal venous sinus. This passage of cerebrospinal fluid into the venous system may be the mere mechanical transmission of one fluid of a lower specific gravity and higher pressure into another through a permeable wall, or there may be some selective action on the part of the veins : in all probability the former simple explanation is the correct one.

Now there is a very significant factor present in most of the cases under discussion -a sufficient explanation for the accumulation of cerebrospinal fluid. In the majority of cases of gunshot wounds with brain destruction and subsequent fibrosis, in heat-stroke by its effect on the surface veins in the brain, in cerebral malaria by the plugging and destruction of surface vessels, in the hæmorrhages of injury with brain contusion and laceration-there is in all a common final result : the loss of a certain percentage of the surface brain area available for the absorption of cerebrospinal fluid. This fluid, formed at a normal rate, is incapable of being absorbed in corresponding ratio, and in consequence there is an accumulation, shown in the minority cases by a condition of internal hydrocephalus (?), and in the majority cases by the condition of cerebral œedema, of which a description has been given. The fluid collects at the base of the brain, first in the 


\section{GUNSHOT WOUNDS OF THE HEAD}

cisterna, and then accumulates in the meningeal spaces over the surface of the brain, where it is seen at operation.

So far as I can see, the only weak link in my chain of argument lies in the fact that I cannot prove my case at the post-mortem table-the mortality after subtemporal decompression is nil, and I have been unable to prove my contention by microscopical and other evidence.

Are there any other explanations available for this excess cerebrospinal fluid ? Is it possible, for example, that they are similar to those described by Warrington as intracranial effusions (serous) of inflammatory origin? Is it possible that the excess fluid is of inflammatory meningeal source? Malaria, heat-stroke, gunshot wounds, etc., might all conceivably lead to some form of chronic meningitis resulting in excess of fluid formation. But, in the cases under discussion, the fluid is always absolutely normal cerebrospinal fluid-there are no extracellular elements, and chemically the fluid is normal in all respects. I do not think, therefore, that these cases are in any respect of inflammatory origin-rather would I accept the view that some of Warrington's cases fall automatically into the group here described.

The theory which I have advanced seems to be best adapted to the conditions as found at operation, and to the results obtained. The other symptoms of the syndrome are all to be explained on the same grounds-the mental depression and uncertainty, the general loss of muscle tone, the exaggeration of knee-jerks, etc., can all be accounted for by the sodden condition of the cerebral cortex, by loss of higher control.

\section{TREATMENT.}

The general lines along which treatment can be conducted in the milder cases are simple enough - and moderately efficacious.

1. The patient should be advised to get a light job, preferably out-of-door work, such as poultry-farming, carrier, country delivery of letters, etc., under a considerate employer who will make all allowances for shortcomings, and for days off when the headaches are more incapacitating.

2. Complete abstinence from alcohol.

3. Regularity of bowels.

4. Avoidance of exposure to the effects of heat.

5. The provision of mild narcotics, which are to be taken during the periods of relapse. I prefer aspirin, pot. bromide, and chloral hydrate, of each 5 to 15 grains.

6. The recumbent position in a quiet, darkened room, during the periods of prostration, if any.

7. The avoidance of excitement of all kinds at all times-cinematographs, for example are to be prohibited.

8. The provision of a suitable pension, sufficing to allay the haunting fear of poverty.

Under such conditions, these patients are usually enabled to carry on with reasonable comfort.

The moderately severe cases are far more difficult to treat. In spite of rigorous action along the lines indicated above, many cases are quite incapacitated from all work, and it is probable that operative measures, decompression, will be adopted more freely in this type of case--this statement being made in view of the generally satisfactory results of decompression.

On the other hand, all palliative measures should be tried first, and I believe that one of the most important is the provision of a living pension rate. This pension should be permanent; there should be no uncertainty about it, no periodic medical boards, etc.

In the more severe cases, after careful consideration of all the circumstances, operative treatment (decompression) can be recommended with considerable confidence.

Of the treatment of headaches by rectal salines, ${ }^{3} \mathrm{I}$ have but little to say. There is, however, about this method so much obvious impracticability that further discussion is useless. In any case, the benefit is purely of a temporary nature-it does not tackle the root of the disease. 


\section{THE BRITISH JOURNAL OF SURGERY}

Treatment by lumbar puncture, though objected to on some similar grounds, requires more careful consideration. It is obviously a method of treatment that should be tried, and I have myself submitted it to a thorough test. I have used it so often that I am clear in my mind as to its general uselessness. I would go further, and say that it is also in many cases harmful. I would tabulate my reasons for these general statements as follows :-

1. Cerebral cedema is not necessarily associated with any excess of fluid in the spinal meninges. Whether my views accounting for the excess cerebral fluid are correct or not, there can be no shadow of doubt that the continuity between the cerebral and spinal cerebrospinal spaces is commonly disturbed. Some of my most marked cases of plus cerebral fluid have been associated with minus spinal fluid-all depends on the meningeal conditions prevailing in the medullary region. In cases of marked cerebral odema there may be such swelling and odema in that region as to prevent the normal continuity between the two systems.

2. Even if the withdrawal of excess fluid by lumbar puncture brings relief, the effect is purely temporary-fluid collects again within a few hours, and the headaches are again as bad as ever.

3. Lumbar puncture frequently makes the headache much worse. The same effect has been observed in the treatment of cerebral and cerebellar tumours by lumbar puncture. The explanation is difficult, though it is probably concerned in some way with the corking up of the medullary region. I have observed, in some few cases, that the immediate effect of lumbar puncture on a patient suffering from a severe attack of headache has been to throw him at once into a condition of agony.

4. Even if the lumbar puncture brings about temporary relief, the process cannot be continued ad infinitum.

In general I am quite opposed to lumbar puncture as a therapeutic measure in these cases. I carry out the measure once, submitting the fluid to chemical, cytological, and bacteriological investigation, and estimating its pressure by spinal manometer. I use Eve's cerebrospinal manometer (Fig. 101).

"The instrument consists of three hollow needles of sizes suitable for children and adults, large or small. These fit on to the stalk of a metal Y-piece.

"To the two other

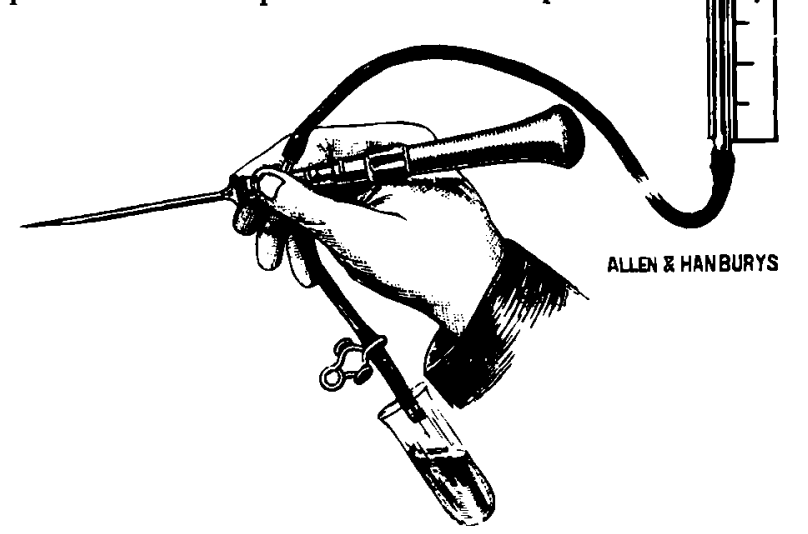

FIG, 101.- Eve's cerebrospinal manometer. branches of the $Y$-piece are

fitted pieces of fine rubber tubing. One tube acts mercly as an exit tube by which to draw off the fluid, and the other leads to the manometer. Both pieces of rubber tubing are provided with spring clips, so that the fluid can either be drawn off or diverted into the manometer. A detachable handle also fits on to the $Y$-piece. This handle is so shaped that it can either be grasped, or held like a pen.

"The three needles are tempered tough, so that the risk of their breaking in situ is avoided. It is important always to keep a wire in them except when in use.

"The manometer consists simply of two lengths of glass tubing, uniting by an inch of rubber tubing, and supported in a groove running the whole length of a folding metal scale. The groove is bridged over at intervals of an inch.

"The hydrometer is capable of measuring the specific gravity of small quantities of fluid 


\section{GUNSHOT WOUNDS OF THE HEAD}

(4 drachms). The whole apparatus except the hydrometer is boiled and brought to the bedside in a shallow dish of boiled water. The apparatus is fitted together in accordance with the diagram, and any contained water is shaken out.

"After introduction, the exit tube being already closed by a clamp, the fluid then rises in the manometer, and the pulsations due to the pulse and respirations are seen. If the fluid fails to appesr, it may often be coaxed by ' milking down' the rubber tube.

"The pressure is recorded when the zero of the manometer is held at the same level as the needle. If the manometer is held vertical, it shows the pressure of the cerebrospinal fluid in terms of a column of water so many inches high."*

\section{GIDDINESS AND NERVOUSNESS.}

Giddiness, present in 77 per cent of cases, and nervousness, in 68 per cent, though slightly improved under bromide treatment, are both but little benefited by decompression operation. It is necessary, therefore, when carrying out decompression operations for the relief of headache, to make it quite clear to the patient that the two minor ailments, giddiness and nervousness, will be but little improved, if at all. They are both, however, of far less disabling nature than headaches. Plating of the defect of the skull may, in my experience, lessen the general nervous symptoms, but it has little effect on the giddiness.

\section{Paralysis.}

It was to be expected that a considerable percentage of the head cases would suffer from permanent paralysis of varying degree. The percentage is less than expected, but quite sufficiently serious (29 per cent). The following table shows the percentage rate according to the nature of the injury incurred :-

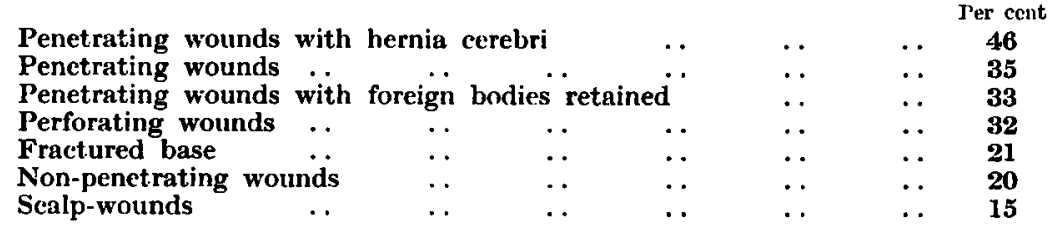

Penetrating Wounds with Hernia Cerebri.-In most cases the injury was received over the anterior and lateral aspects of the skull. Patients with occipital and cerebellar hrrniac scldom survived; cerebellar cases were especially fatal. When the protrusion. involved the motor cortex, hemiplegia resulted, and in many cases the paralysis is of a permanent nature; but it may be added that in some cases the ultimate result was extraordinarily good-the patient recovering almost full power.

Penetrating Wounds, with or without Foreign Body Retained, come next in the list of cases presenting permanent paralyses, but it is interesting to note that the retention of a foreign body does not appear in itself to present any additional paralytic disability : 33 per cent with such bodies retained, 85 per cent where none are present, whether removed early or at a later date. In other words, the paralysis results from damage done by the penetration of the foreign body, perhaps increased by attempts at removal, not from the retention of the body itself. This point must not be laboured - no argument against the early judicious removal of foreign bodies is advanced - but it should certainly act as some sort of deterrent against ill-judged and promiscuous attempts at foreign-body removal, both early and late.

Perforating Wounds, 32 per cent, come next in the list, the lessened paralytic rate, being due in part to the high death-rate of this class of injury--only the slighter cases recover as a rule, the bi-frontal, etc.

In Fractured Base, Non-penetrating Wounds, and Scalp-Wounds, the paralytic rates 21, 20, and 15 per cent respectively, are obviously dependent on brain lacerations and

* I think that, under normal conditions, the fluid rises to a height of 6 to 8 in. When under excessive pressure, I have seen the fluid running from the top of the manometer, i.e., to a height of 24 in. 
contusions, surface hæmorrhages, both external to and within the dura mater. It is a debatable point, but one certainly worth consideration, as to whether some of these cases would not have benefited by early operation, with the hope of evacuating extradural or intradural blood-clot (see Scalp-wounds, p. 94).

A large number of these paralytic cases have improved under treatment, massage, radiant heat, re-education, etc., but many remain more or less totally incapacitated. The proportionate improvement in upper limb, lower limb, and face has followed the normal course as regards the degree and rate of recovery in the three regions mentioned-face recovering first and most, followed by the lower extremity, the upper always lagging behind. Recovery has been exceptionally poor after injuries of the superior longitudinal sinus-Sargent's longitudinal sinus syndrome. ${ }^{4}$

Allusion will be made later to operative treatment, but it would be wise to state here that plating or closure of the defect in the skull brings about, in my experience, but very little, if any, benefit for this type of case.

\section{FITS.}

The prevalence of fits after war injuries of the head is of the utmost importance. Early in the war it was stated that the percentage of cases in which fits developed was very low. That also was my experience; but I was sceptical as to whether the picture would not change. In this series, fits were reported in 25 per cent of cases, in the following percentages according to the lesion :-

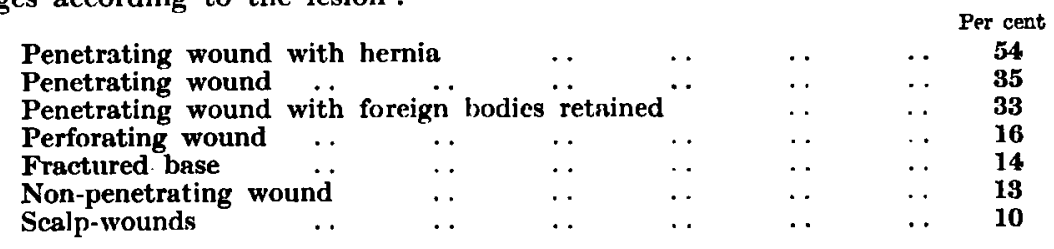

This list should be compared with that illustrating the rate of paralysis in relation to the site and nature of the injury-there is a close resemblance.

Nature and Frequency of Fits.-On analysis, it was found that the fits could be divided into four groups, viz. :-

\begin{tabular}{|c|c|c|c|c|c|c|}
\hline Epileptiform & $\ldots$ & & & & $\cdots$ & $\begin{array}{c}\text { Per cent } \\
\mathbf{5 7}\end{array}$ \\
\hline Jacksonian . & . & . & . & . & . & 23 \\
\hline Fainting $\quad \ldots$ & . & $\cdots$ & . & $\cdots$ & . & 16 \\
\hline Slight and uncertain & .. & $\cdots$ & $\cdots$ & $\cdots$ & $\cdots$ & 4.5 \\
\hline
\end{tabular}

It is noteworthy that the more severe types of fit were associated with the more serious lesions. Thus, in non-penetrating wounds there was 1 case of Jacksonian epilepsy, 6 cases of epileptiform seizures, 4 of fainting, and 5 of a slight nature ; whilst in penetrating wounds there were 20 cases of Jacksonian and 42 of epileptiform fits, 2 only of the fainting type, and $\gamma$ of the slight variety.

The term 'epileptiform' is used for those generalized fits in which there was sudden loss of consciousness, followed by struggling, often of a violent description, and sometimes necessitating restraint with the help of three or four assistants; the patient passing urine involuntarily, biting the tongue, and remaining unconscious for varying periods of time, a few minutes to hours.

The term 'fainting' is used for a type of fit of which I have had little previous experience-a sudden relapse into the dream-state, with no biting of the tongue, etc., enduring a few minutes only, and leaving the patient tired, uncertain as to what has happened, and complaining of severe headache-attacks of petit mal of sorts.

Perhaps these 'fainting' fits, and other types of fit, may be explained by a " vasaconstriction reaction of the minute vessels in the cortex, thus causing anæmia of the brain and, in consequence, a greatly increased sensitiveness to internal and external stimuli, the so-called 'Stokes-Adams' syndrome ". 5 


\section{GUNSHOT WOUNDS OF THE HEAD}

In the treatment of these fit cases, my experience is such that I do not consider operative measures are of much avail, though in some instances the plating of the defect (after Sargent's method) has brought about some benefit. Prolonged and assiduous treatment with bromides, luminal, etc., should be carried out, combined with admission to hospital during the more severe stages. It is remarkable how the condition can be controlled when the patient is properly looked after. This improvement is due, not to the medical treatment of a neurasthenic case, but to the transference of a patient inclined to fits from the economic and family difficulties and exciting incidents of home life to the quiet of hospital, with its systematic and sympathetic treatment, associated with that confidence in the medical man in charge of the case which is so essential.

Luminal, first recommended to me by Sir Frederick Nott, has received a good trial. On the whole, I am inclined to believe that it is the most efficacious drug in fit control, given as a rule in 21 -gr. doses night and morning. I note, in a recent paper, ${ }^{8}$ that stress is laid on the establishment of tolerance in patients under luminal, the frequent necessity of dosage increase to obtain control, and the bad effects produced by sudden withdrawal of the drug. I have not noticed these effects myself, though I have recently seen one of my patients under luminal who took five times the dose by accident and who was brought to the hospital in a state of violent excitement closely simulating over-indulgence in alcohol. In any case the drug must be given with caution, its effect carefully noted, and the patients warned against overdose.

\section{GENERAL REMARKS ON WORK CAPACITY.}

I should like to preface this section by a statement to the effect that, of the 400 to 500 cases, there was not a single case in which the patient stated that he could work and could not get work. Whether this applies to the immediate present, I cannot say. My investigations have shown clearly that the slackers are but few in number. Here is a table showing how the men are working, in relation to their wounds and general disabilities.

\begin{tabular}{|c|c|c|c|c|c|}
\hline & & & $\begin{array}{l}\text { No work } \\
\text { Per cent }\end{array}$ & $\begin{array}{l}\text { Light work } \\
\text { Her cent }\end{array}$ & $\begin{array}{l}\text { Heavy work } \\
\text { Per cent }\end{array}$ \\
\hline Scalp-wounds & . & .. & 10 & 19 & 70 \\
\hline Non-penetrating wou & inds & . & 19 & 24 & 56 \\
\hline Penetrating wounds & & $\begin{array}{ll}\ldots & \ldots\end{array}$ & 38 & 24 & 38 \\
\hline $\begin{array}{l}\text { Penetrating wounds } \\
\text { Penetrating wounds }\end{array}$ & $\begin{array}{l}\text { with } \\
\text { with }\end{array}$ & $\begin{array}{l}\text { hernia cerebri } \\
\text { foreign bodies }\end{array}$ & 69 & 20 & 10 \\
\hline retained & .. & . $\quad \ldots$ & 43 & $\mathbf{3 6}$ & 22 \\
\hline Perforating wounds & .. & . & 21 & 26 & 53 \\
\hline Fractured base & . & $\cdots$ & 14 & $\mathbf{3 6}$ & $\mathbf{5 0}$ \\
\hline
\end{tabular}

Is it not rather extraordinary that, in the case of penetrating wounds with retained foreign bodies in the brain substance, 58 per cent should work, light or heavy, and that, in perforating wounds, 79 per cent should be earning their living in whole or in part ? As another example of the work capacity of these patients, is it not marvellous that one of my patients, with a shrapnel bullet in the very centre of the brain, should be working eight hours a day at pattern-making ?

\section{RETAINED FOREIGN BODIES,}

It will be noted that some arguments have been deduced from time to time against the removal of foreign bodies from the brain substance. This statement must be accepted advisedly. All experience shows that the immediate removal of foreign bodies should be encouraged, provided that, in the process of removal, every precaution be taken against increasing the damage already incurred by the penetration into the brain of the foreign body. It is clear, however, that such bodics may remain encysted in the brain substance without producing any harm whatsoever. On the other hand, there is some remote chance of a 'flare' (see Postscriptum, p. 125). These flares, however, are very rare, and it is wise to advise caution in the ranks of the younger generation, as regards the removal of the foreign body, both early and late. 


\section{DECOMPRESSION, WITH DETAILS OF 40 CASES.}

Subtemporal decompression is the routine operation carried out for the relief of headache. This operation has but little, if any, effect upon the other symptoms of the

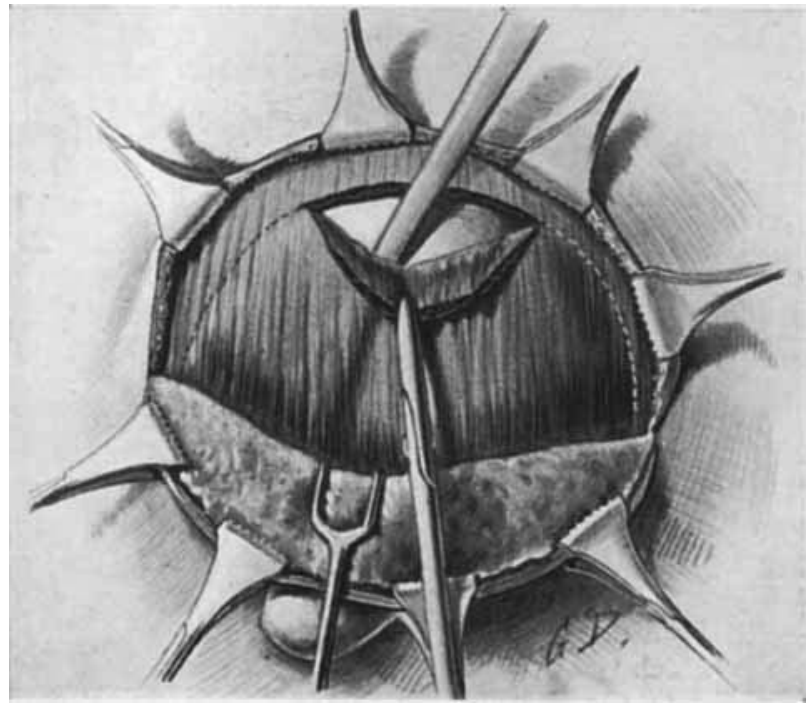

Fic. 102.-Subtemporal decompresion. Stage 1. Harnostatic forceps applied to the scalp margin. Tempornl muscle incised and stripped from the bone by priosteal elevator.

intradural hypertension should be re

intradural hypertension should
far as headache is concerned.

We knew something about 'œdema of the brain' long before the war; but the first of the series of cases on which this paper is based was operated on in Indiaa soldier from Mesopotamia, invalided to India with fearsome headaches after heat-stroke.

I think I adopted Cushing's method of decompression, the intermusculotemporal route, and this course I have adopted a few times in subsequent cases, usually those of the milder description. It presents some advantages over the method described below, but it does not permit of the degree of exposure required for the necessary brain examination, the field of operation is cramped, and there is always sore risk of damage to the anterior or main branch of the middle meningeal artery, more especially where that vessel runs in a canal or groove in the bone. Consequently, I am accustomed to decompress the temporal region after the following manner :syndrome-giddiness, insomnia, nervousness, etc.-and all my cases of decompression, 40 of which are appended, were carricd out with the main object of relieving headache.

As regards the rationale of this decompression operation, I believe that in the great majority of cases the headaches are dive to increased hypertension, the result of excess cerebrospinal fluid, and that the rational treatment is to trephine over some 'silent' area of the brain, preferably on a level with the base of the brain (for more efficient drainage), in some situation where the scar is inconspicuous and where the osseous defect can be protected with muscle-flap. The excess fluid would be permitted a means of escape into scalp tissues where it is more readily absorbed, the relieved at once, and immediate benefit obtained so

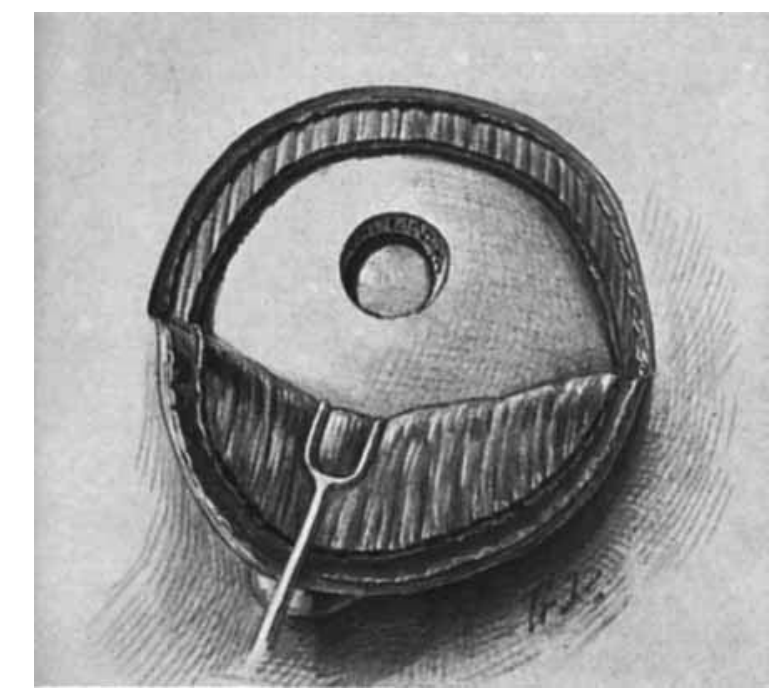

FIG. 103.-Subtemnoral decompression. Stage :. Temporal musclo turnck dow:. Bone trephined over centre of exposed area. 


\section{GUNSHOT WOUNDS OF THE HEAD}

The apex of the ear is stitched to the cheek, to get it out of the way, after which a curved incision is made, the convexity of which lies about one inch below the temporal crest, the ends curving downwards as seen in the illustration (Fig. 102).

The incision should be commenced at the summit of the curve, and carried down to expose the temporal fascia-about one inch at a time, hæmostatic forceps being applied to either cut edge of scalp, thus obtaining a practically bloodless field. When the incision is completed, the forceps are removed one by one, and bleeding points secured and tied in the ordinary manner.

The skin and subcutaneous flap is turned down for about three-quarters of an inch, when the temporal fascia and muscle are divided to the bone, again at the summit of the wound, about half an inch below the margin of the scalp incision; the temporal muscle is then seized with Lane's forceps, and the muscle stripped up from the bone with a periosteal elevator, down to the level of the attachment of the ear to the skull, being divided in front and behind with the scissors, in

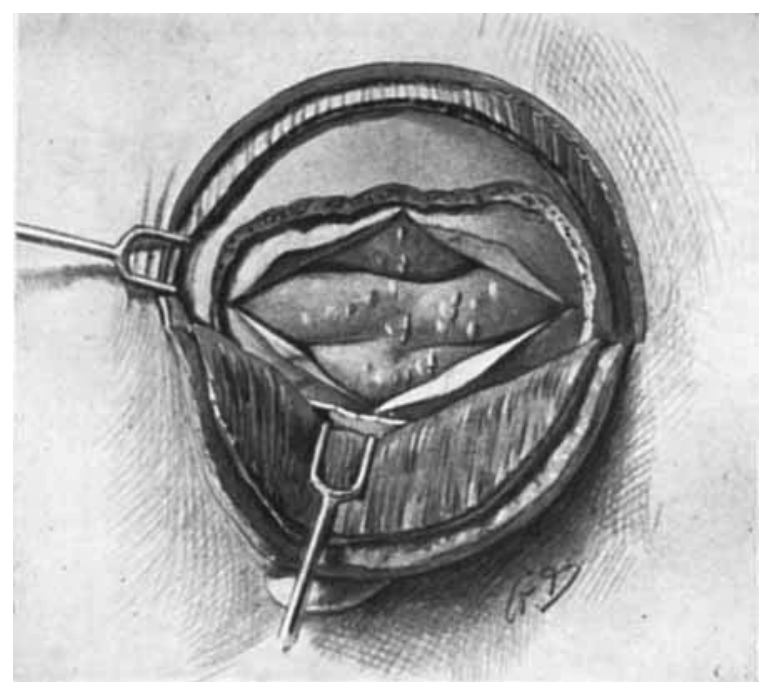

Fia. 105,-Subtemporal decompresslon. Slage 4. Diagrammatic representation of the cedematous and sodden brain, showing the area exposed, and the drainage space provided by the operation.

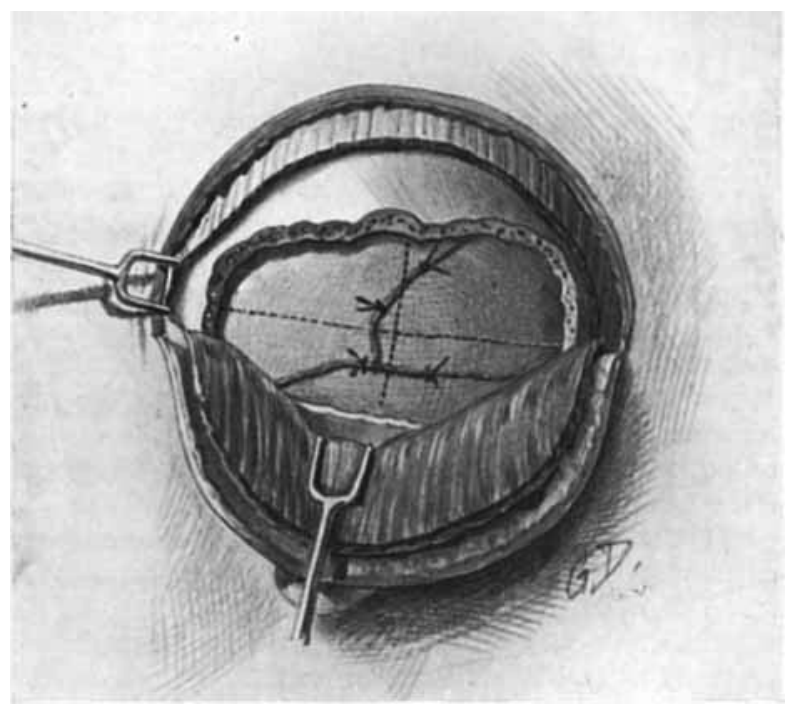

FIt. 104.- Subtemporal decompression. Stage 3. Bone cut away in the forward, backward, and downward directions. Ligature of posterior branch of middle meningesl artery and line of dura incision.

N.B.-In practice more bone should be cut away than is represented in the illustration-more especially in front or below, in relation to the retractors.

a line with the skin incision. Any bleeding points are secured. The pericranium is stripped away with the muscle. A half-inch trephine is applied to the centre of the bone exposed, and the disc removed (Fig. 103). There is no fear of damaging the middle meningeal artery, the trephine area being situated in the angle between its anterior and posterior branches. The appearance of the dura exposed usually shows whether the diagnosis is correct or not, and whether a condition of cerebral cedema is existent or not. In this condition, the dura itself is seen to be cedematous, and to have lost its sheen and translucency. As a rulc, moreover, it is not tight nor does it bulge, but pulsation is absent.

Before opening the dura mater, the bone is nibbled away, in the forward and backward directions, but more especially in the dozenzard, towards the base of the skull and base of the brain, 
towards the level of the zygoma and attachment of the ear. The muscle-flap is well held up, and the attached muscle, in front and behind, well retracted so as to allow of the free application of the nibbling forceps, an aperture being framed which is not less than 2 inches in the anteroposterior direction, and $1 \frac{1}{2}$ inches in the vertical, the aperture lying throughout underneath the temporal muscle, and reaching down to the base of the skull. When nibbling in the anterior direction, care must be taken to avoid injury to the anterior branch of the middle meningeal artery-the posterior will cross the area of dura exposed, in the horizontal direction.

The lower the aperture is situated, and the nearer to the base of the brain, the more free will be the escape of excess cerebrospinal fluid when the dura is opened.

The posterior branch of the meningeal artery will require ligature in two places before the dura is opened. This is done with an intestinal needle, threaded with fine silk, the needle being passed so as to surround the vessel without injuring the underlying piaarachnoid. If the point of the needle enters the subdural space, when a condition of cedema is present, fluid will escape through the needle-hole, sometimes in a fine spurt, thus establishing the diagnosis even before the dura is properly opened. The dura is now incised, in a crucial manner, and slit up in the four directions, right up to the margins of the bone aperture (Figs. 104 and 105).

If the conditions are as expected, cerebrospinal fluid escapes freely, and a blunt spatula, insinuated beneath the temporosphenoidal lobe, lifting it up, will allow of the escape of more fluid.

The dura is left open. The temporal muscle is approximated with a few catgut sutures, and the fascia sewn up so far as circumstances permit. The skin is sutured with fine salmon-gut, and the wound closed without drainage. The excess fluid escapes into the tissues of the side of the head and face-sometimes leading, in marked cases of oedema, to considerable odema of the face. This condition soon mends.

The wound is painted over with picric or iodine, and layers of gauze are laid firmly and evenly over the wound.

The stitch is removed from the ear, the ear smeared with ointment, and the dressings are secured with bandages, care being taken to see that the ears are flat, not bent over.

The patient is put back to bed, in the sitting-up position, and kept lightly under the influence of morphia for the first twenty-four hours. The wound is redressed completely the day after the operation.

\section{General or Local Ansesthetic?}

There are points in favour of either method. The main point in favour of local anæsthesia is related to the question of vomiting-the increase of intracranial pressure associated with the act of vomiting, and the fact that the brain is now unsupported in the region of the aperture, renders it highly desirable that the vomiting element should be eliminated, if possible. There can be no question that vomiting is of less likely occurrence after a local anæsthetic.

On the other hand, there can be no question that the operation can be conducted more freely and more easily under a general anæsthetic, and if complications should arise, for example troublesome bleeding from a meningeal vessel, the difficulties can be overcome more readily.

Local.-If the operation is to be conducted at 1.30, the patient at 1 o'clock receives a hypodermic of

$\begin{array}{llllll}\text { Morphine } & . . & . & \ldots & \ldots & \text { gr. } 1-4 \\ \text { Atropine } & \ldots & . & \ldots & \cdots & \text { gr. 1-100 } \\ \text { Hyoscine } & . & \ldots & \ldots & \cdots & \text { gr. } 1-100\end{array}$

and a second hypodermic, same strength, at 1.15 .

These injections should be given when the patient is quiet in the anæsthetic room, on the operating table. The eyes should be covered and the ears filled with wool. Then at 1.30 he is wheeled into the theatre and the 'local' anæsthetic given. I am accustomed to use Gray's syringe, with a 2 per cent solution of novocain, freshly prepared, to ench 


\section{GUNSHOT WOUNDS OF THE HEAD}

10 c.c. of which are added 5 drops of a 1-500 solution of adrenalin. The solution is injected subcutanously in the line of the proposed incision, and along the base of the flap, blocking the operation field (Fig. 106).

I must admit that I was much surprised, when doing my first case under this method, to find that not only was the cutaneo-muscular flap formation painless, but - that trephining and enlargement of the aperture were painless also. During the first few minutes of the operation the patient is often nervous, and during the trephining may express some resentment; but $I$ have never heard the patient complain of actual pain. The dural incision is passed unnoticed, as also is digital examination of the brain.

Of course the psychology of the patient must be taken into consideration, and it is desirable to have a skilled anæsthetist present in case his services should be required.

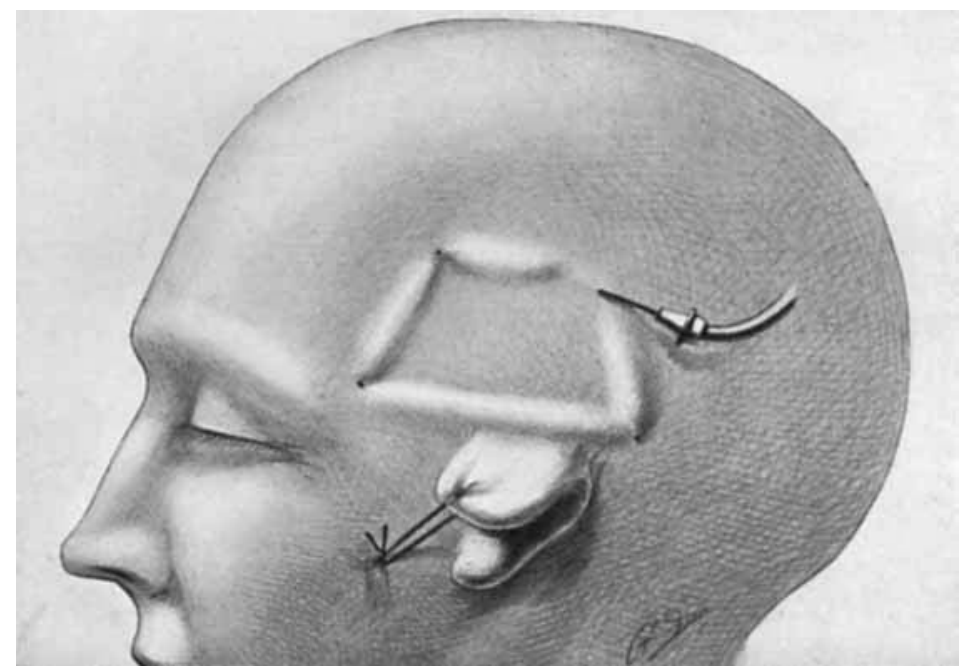

FIG. 106.-Infiltration of the operation area with norocain and adrenalin solution.

As to the side on which the operation should be carried out, the right side, in righthanded individuals, is the side of choice, but $I$ never hesitate to operate on the left side - the possibility of interfering with Broca's motor speech area should not arise. I am sure, however, that one should be influenced by any localization of headache-operating on the side on which it is the more severe. Also, it is advisable to operate on the same side as that on which the injury was received.

After-Treatment.-It is most desirable that these patients should be kept in bed for not less than three weeks after the operation. This is often very difficult to carry out in practice, for, being relieved of headache after months or years of suffering, patients become very intractable. It is desirable, also, that there should follow a long period of convalescence, at some quiet spot, for three months or more.

Remote Results of Subtemporal Decompresslon.-The immediate benefit, amounting usually to complete relief from the old headache, is dependent on the escape of the pent-up fluid from the intradural space. It would be anticipated, however, that as the wound heals and scarring occurs, the aperture would become closed with scar-tissue, with a return, therefore, of the old headaches. I expected this result-it ought so to be, and to some extent it is so; but not to the degree anticipated. On following up the various cases, two to four years after operation, I have been gratified at the ultimate results in general. There have been some more or less complete failures, and in quite a number the headaches returned again, after a few months, though it is most exceptional for them 
at all to resemble the fearful and constant type experienced previously. In some cases the cure is apparently permanent. A complete account with after-results is appended, and it will be noted that the unsatisfactory cases presented very serious primary lesions. In weighing the pros and cons of the operation it should be noted also that the 40 cases reported were the most severe cases of war headache that $I$ have encountered in the last six years.

Cholce of Case.-The following points should be considered before advising operative procedures :-

1. It matters not how long the headaches may have persisted; in fact, the longer the more likely the success.

2. Constant headaches, more especially when accompanied by frequent periods of exacerbation-being associated as a rule with marked oedema-are more amenable to treatment than the inconstant cases.

3. The prognosis is better :-

i. When the headaches are accompanied by that facial appearance of depression and misery to which allusion has already been made.

ii. When the patient is 'fed-up' with his trouble.

iii. When marked excess of cerebrospinal fluid is found on lumbar puncture.

iv. When there is no bleeding at operation and no tendency to hæmatoma.

v. When marked cerebral cedema is found at operation.

vi. When the operation is followed by little or no vomiting.

vii. When the patient is able and willing to follow out the after-treatment prescribed.

An analysis of $\mathbf{4 0}$ cases of subtemporal decompression shows that the operation was carried out for the following conditions :-

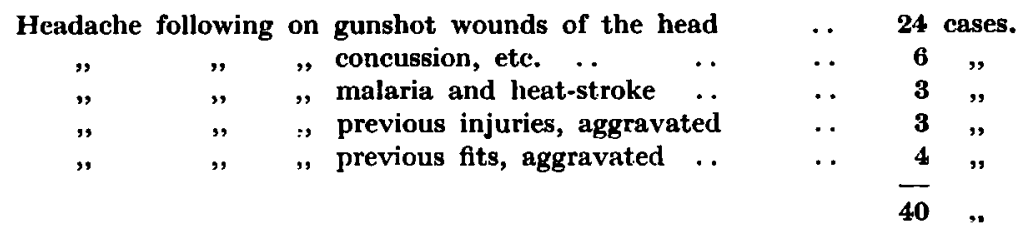

It is interesting to note that headaches in general, apart from these 40 decompression cases, were associated usually with non-penetrating and grazing wounds of the head, cases in which the primary operation, if any, was of but slight decompressive nature. There was a considerable revulsion of feeling against Sargent's extensive craniectomies in the early stages of the war, but $I$ am quite certain that headaches are of more frequent occurrence in those cases where the surgeon has abstained from operation or carried out a very minor form of bone removal.

This would suggest that, although primary excision of the scalp-wound and primary suture are advisable in general, it is best to carry out also a fairly extensive removal of bone. (See below.)

SYNOPSIS AND CRITICISM OF 40 CASES OF DECOMPRESSION (delails in Tahle).

1. Cause of Symptoms:-

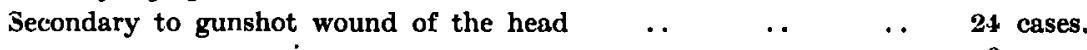

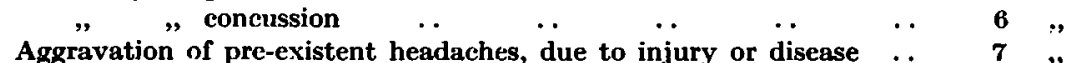

Secondary to heat-stroke, cerebral malaria, etc.

$\cdots \frac{3}{40} "$ 


\section{GUNSHOT WOUNDS OF THE HEAD}

2. Operation carried out for the relief of :-

Headache only

Headache and fits.

$\cdots$

3. Operation :-

Left subtemporal decompression

Right subtemporal decompression

Bilateral subtemporal decompression ..

4. Conditions found at operation :-

Marked cedema .. ..

Moderate degrec of cedema ..

Slight $\propto$ dema.

Practically no cedema, mainly

characterized by bulging ..

$$
\begin{array}{rrrrrr}
. & \ldots & \ldots & \ldots & 32 & \text { cases. } \\
\ldots & \ldots & \ldots & \ldots & 6 & " \\
\ldots & \ldots & \ldots & \ldots & 2 &
\end{array}
$$

Immediate effect of the operation on the headache:-

Very great immediate relief, amounting in most cases to complete

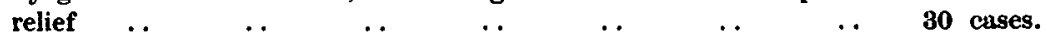

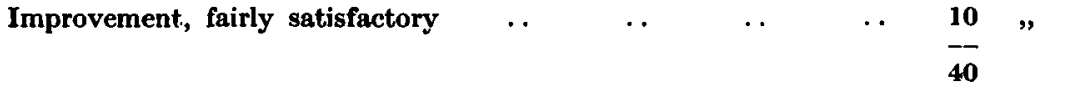

6. Remote effect of the operation on the headache :-

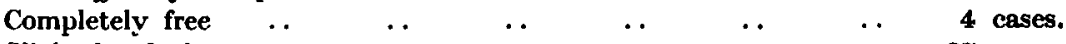

$\begin{array}{lllllllll}\text { Slight headaches } & \ldots & \ldots & \ldots & \ldots & \ldots & \ldots & \mathbf{2 7} & \text { ", }\end{array}$

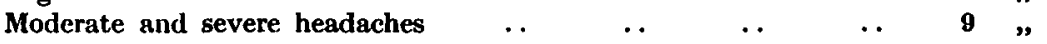

$\overline{40}$

(Note that operation was only advised and carried out for the very severe cases.)

7. Remote effect of the operation on the fits:-

Patients who have had no more fits or else fits of quite slight nature

Patients who have fits much the same as before, though in some

the fits may be less violent and frequent .. $\ldots$

6 cases.

$\frac{9}{15} "$

(I have reason to believe that this relatively satisfactory result has not been borne out by subsequent cases.)

8. Work capacity of the patient upon whom subtemporal decompression has been carried

out :-

$\left.\begin{array}{lrlllll}\text { Doing ordinary work } & \ldots & \ldots & \ldots & \ldots & 17 \\ \text { Light work } & \ldots & \ldots & \ldots & \ldots & \ldots & 10\end{array}\right\} \mathbf{2 7}=67 \cdot 5$ per cent.

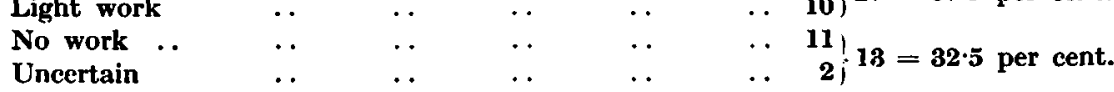

$\overline{40}$

This working capacity should be compared with the general average, viz. :-

$\begin{array}{llllllll}\text { Scalp-wounds } & \ldots & \ldots & \ldots & \ldots & \ldots & \ldots & 89\end{array}$

$\begin{array}{lllllll} & \ldots & \ldots & \ldots & \ldots & \ldots & \\ \text { Non-penetrating wounds } & \ldots & \ldots & \ldots & \ldots & \ldots & \mathbf{8 0}\end{array}$

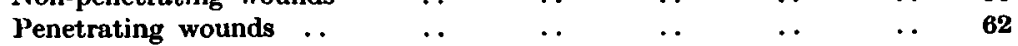

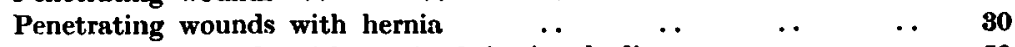

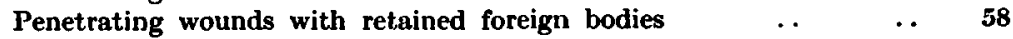

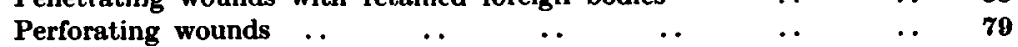

$\begin{array}{llllllll}\text { Fractured base } & \ldots & \ldots & \ldots & \ldots & \ldots & \ldots & 86\end{array}$

(Note that the 40 cases submitted to decompression operations were previously totally incapacitated.)

vor. X.-No. 37 . 


\section{THE BRITISH JOURNAL OF SURGERY}

\section{Table II.-LIST OF 40 DECOMPRESSION CASES :}

\begin{tabular}{|c|c|c|c|c|}
\hline DATE AND NATURE OF INJURY & SYMPTOMS & OPERATTON AND DATE & $\begin{array}{c}\text { PRESENT STATE AS } \\
\text { TO HEADACHES }\end{array}$ & $\begin{array}{l}\text { DIN OPERATION } \\
\text { BRIYG RELIEF : }\end{array}$ \\
\hline $\begin{array}{l}\text { Epilepsy and headaches since } \\
7 \text { years old. Aggravated by } \\
\text { service in Mesopotamia }\end{array}$ & $\begin{array}{l}\text { Severe epileptic fits, with } \\
\text { constant and severe head- } \\
\text { aches }\end{array}$ & $\begin{array}{l}\text { Left subtemporal decom. } \\
\text { pression, Sept., } 1916 . \\
\text { Edema slight }\end{array}$ & $\begin{array}{c}\text { Slight } \\
\text { occasional }\end{array}$ & Yes \\
\hline $\begin{array}{l}\text { Epilepsy and headaches since } \\
\text { childhood. Aggravated by } \\
\text { service in Gallipoli and Meso. } \\
\text { potamia }\end{array}$ & $\begin{array}{l}\text { Severe epileptic fits, with } \\
\text { prostrating headaches }\end{array}$ & $\begin{array}{l}\text { Left subtemporal decon- } \\
\text { pression, Sept., } 1916 . \\
\text { Marked œdema }\end{array}$ & $\begin{array}{l}\text { Slight } \\
\text { occasional }\end{array}$ & $\begin{array}{l}\text { Yes, quite } \\
\text { satisfied }\end{array}$ \\
\hline $\begin{array}{l}\text { Depressed position of vault in } \\
\text { 1911. Headaches, previously } \\
\text { slight, became much aggra- } \\
\text { vated by service in Meso- } \\
\text { potamia }\end{array}$ & $\begin{array}{l}\text { Persistent headaches, with } \\
\text { periodic prostration. In. } \\
\text { somnia. Oceasional } \\
\text { vomiting }\end{array}$ & $\begin{array}{l}\text { Right subtemporal decom- } \\
\text { pression, Nov., } 1916 . \\
\text { Marked odema }\end{array}$ & $\begin{array}{l}\text { Occasional se- } \\
\text { vere, gener- } \\
\text { ally slight } \\
\text { and incon- } \\
\text { stant }\end{array}$ & $\begin{array}{l}\text { At first, yes } \\
\text { Now, not } s \\
\text { good }\end{array}$ \\
\hline $\begin{array}{l}\text { Previous history of fits and } \\
\text { headache, much aggravated } \\
\text { by service in Mesopotamia. }\end{array}$ & $\begin{array}{l}\text { Severe and prolonged fits. } \\
\text { Persistent and severe head- } \\
\text { aches. Periodic prostra- } \\
\text { tion }\end{array}$ & $\begin{array}{l}\text { Right subtemporal decom. } \\
\text { pression, Jan., } 1917 \text {. } \\
\text { Marked cerebral œdema }\end{array}$ & No headaches & Yes \\
\hline $\begin{array}{l}\text { Meningitis(?) when } 14 \text {. Life } \\
\text { miserable. Worse after ser- } \\
\text { vice in Mesopotamia }\end{array}$ & $\begin{array}{l}\text { Chronic and persistent head- } \\
\text { aches, with exacerbations }\end{array}$ & $\begin{array}{l}\text { Left subtemporal decom- } \\
\text { pression, Jan., } 1917 . \\
\text { Marked oedema }\end{array}$ & None & Quite satisfie \\
\hline $\begin{array}{l}\text { (?) Heat-stroke, (?) Cerebral } \\
\text { malaria in Mesopotamia }\end{array}$ & $\begin{array}{l}\text { Violent epileptiform fits, } \\
\text { severe headaches, often } \\
\text { with prostration }\end{array}$ & $\begin{array}{l}\text { Left subtemporal decom- } \\
\text { pression, Feb., } 1917 \text {. } \\
\text { Som } \theta \text { d em a, marked } \\
\text { genoral bulging }\end{array}$ & None & Yes \\
\hline $\begin{array}{l}\text { G.S.W. Mastoid, Dec, } 1916 \text {, } \\
\text { depressed, non-penotrating }\end{array}$ & Persistent headaches & $\begin{array}{l}\text { Left subtemporal decom- } \\
\text { pression, April, 1917. } \\
\text { CEdema well marked }\end{array}$ & $\begin{array}{l}\text { Severe at } \\
\text { times }\end{array}$ & $\begin{array}{l}\text { Somewhat bel } \\
\text { ter than br } \\
\text { fore the opel } \\
\text { ation }\end{array}$ \\
\hline $\begin{array}{l}\text { Heat-stroke, } 1915 \text {, in Meso- } \\
\text { potamia }\end{array}$ & $\begin{array}{l}\text { Violent epileptiform fits, } \\
\text { with severe and persistent } \\
\text { headache }\end{array}$ & $\begin{array}{l}\text { Right subtemporal decom- } \\
\text { pression, August, } 1917 . \\
\text { Marked tension, but little } \\
\text { odema }\end{array}$ & At times & $\begin{array}{l}\text { Yes, good } \\
\text { first. } \\
\text { not so good }\end{array}$ \\
\hline $\begin{array}{c}\text { G.S.W. Left frontal, pene- } \\
\text { trating, June, } 1917 \\
\text { : }\end{array}$ & $\begin{array}{l}\text { Very severe and constant } \\
\text { headache. Severe exacer- } \\
\text { bations }\end{array}$ & $\begin{array}{c}\text { Left subtemporal, Dec., } \\
\text { 1917. Marked odema. } \\
\text { Right subtemporal, Oct., } \\
\text { 1918. Less œdema }\end{array}$ & $\begin{array}{l}\text { Varying from } \\
\text { very slight } \\
\text { to moderate, } \\
\text { inconstant }\end{array}$ & $\begin{array}{cr}\text { Considerabl } \\
\text { relief fror } \\
\text { fist opera } \\
\text { tion, mor } \\
\text { after r th } \\
\text { second }\end{array}$ \\
\hline $\begin{array}{l}\text { G.S.W. Frontal, non-pene- } \\
\text { trating, Oct., } 1917\end{array}$ & $\begin{array}{l}\text { Persistent headaches, with } \\
\text { exacerbations }\end{array}$ & $\begin{array}{l}\text { Left subtemporal, March, } \\
\text { 1918. CEdema moderate }\end{array}$ & $\begin{array}{c}\text { Slight } \\
\text { occasional }\end{array}$ & Yes \\
\hline $\begin{array}{l}\text { G.S.W. Left temporo-pari- } \\
\text { etal, removal of bullet from } \\
\text { brain, Feb., } 1917\end{array}$ & $\begin{array}{l}\text { Headaches, aphasia, hemi- } \\
\text { anopsia. Fits }\end{array}$ & $\begin{array}{l}\text { Removal of bullet, March, } \\
1917 \text {. Left subtemporal, } \\
\text { March, } 1918 . \quad \text { General } \\
\text { bulging }\end{array}$ & $\begin{array}{c}\text { Slight } \\
\text { occasional }\end{array}$ & $\begin{array}{l}\text { Lessening } \\
\text { headaches an } \\
\text { giddiness }\end{array}$ \\
\hline $\begin{array}{l}\text { G.S.W. Left temporal and } \\
\text { occipital regions, severe brain } \\
\text { laceration and numerous } \\
\text { small foreign bodies remain- } \\
\text { ing in brain }\end{array}$ & $\begin{array}{l}\text { Violent headaches, with } \\
\text { screaming fits. } \\
\text { Streptococcal meningitis. }\end{array}$ & $\begin{array}{c}\text { Right subtemporal, April, } \\
\text { 1818. General bulging }\end{array}$ & $\begin{array}{l}\text { Great relief at } \\
\text { first, then } \\
\text { recurrence, } \\
\text { and now } \\
\text { better again }\end{array}$ & Yes \\
\hline $\begin{array}{l}\text { G.S.W. Left temporal, July, } \\
1916 \text {, with laceration of brain }\end{array}$ & $\begin{array}{l}\text { Censtant headaches, with } \\
\text { occasional epileptiform fits. } \\
\text { Dull mentally. }\end{array}$ & $\begin{array}{l}\text { Left subtemporal, May, } \\
\text { 1918. General œdema }\end{array}$ & $\begin{array}{c}\text { Slight } \\
\text { occasional }\end{array}$ & Instant relief \\
\hline $\begin{array}{l}\text { G.S.W. Fronto - parietal, } \\
\text { ? penetrating, } 12 / 4 / 18\end{array}$ & $\begin{array}{l}\text { Very severe and constant } \\
\text { headaches, with exacerba- } \\
\text { tions }\end{array}$ & $\begin{array}{l}\text { Left subtemporal decom- } \\
\text { pression, } 31 / 5 / 18 \text {. } \\
\text { Moderate degree of cedema }\end{array}$ & Occasional & Yes \\
\hline
\end{tabular}




\section{WITH PARTICULARS AND END-RESULTS.}

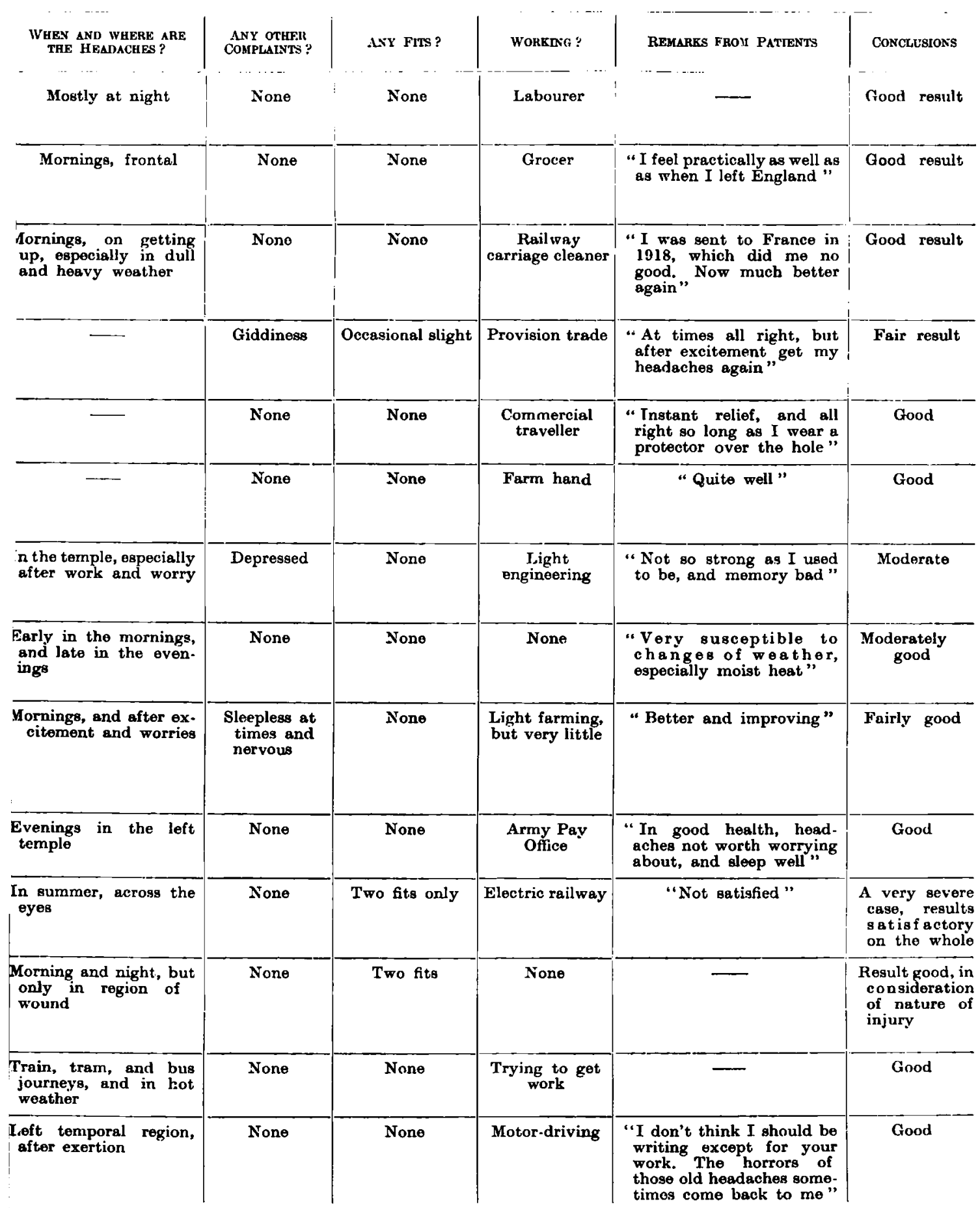


Table II.-LIST OF 40 DECOMPRESSION CASES :

\begin{tabular}{|c|c|c|c|c|}
\hline $\begin{array}{l}\text { DATE AND NATURE OF INJURY } \\
\end{array}$ & SIMPTONS & OPFRATION AND DATE & $\begin{array}{l}\text { PRESENT ETaTe AS } \\
\text { TO HEADACHFS }\end{array}$ & $\begin{array}{l}\text { DID OPERATION } \\
\text { BRENQ RELIFF? }\end{array}$ \\
\hline $\begin{array}{l}\text { Concussion in } 1905 \text {, headaches } \\
\text { frequent, and aggravated } \\
\text { by service in India, } 1916- \\
1917\end{array}$ & $\begin{array}{l}\text { Constant headaches, with } \\
\text { frequent and violent ex- } \\
\text { acerbations. "No interest } \\
\text { in life." Some fits }\end{array}$ & $\begin{array}{l}\text { Left subtemporal decom- } \\
\text { pression, } 15 / 8 / 18 \text {. } \\
\text { Marked cerebral } \text { edema }\end{array}$ & $\begin{array}{l}\text { More or less } \\
\text { constant }\end{array}$ & "Not quite" \\
\hline $\begin{array}{l}\text { G.S.W. Right occipital, pene- } \\
\text { trating, } 18 / 4 / 18\end{array}$ & $\begin{array}{l}\text { Constant headaches and } \\
\text { apathy }\end{array}$ & $\begin{array}{l}\text { I.eft subtemporal decom- } \\
\text { pression, 30/8/18. Very } \\
\text { marked œdema }\end{array}$ & $\begin{array}{c}\text { Slight } \\
\text { occasional }\end{array}$ & Yos \\
\hline $\begin{array}{l}\text { G.S.W. Right frontal, pene- } \\
\text { trating. Date? }\end{array}$ & $\begin{array}{l}\text { Constant headaches, with } \\
\text { exacerbations. Depression } \\
\text { and fits }\end{array}$ & $\begin{array}{l}\text { Left subtemporal decom- } \\
\text { pression, } 10 / 11 / 18 \text {. } \\
\text { Marked cedema. }\end{array}$ & $\begin{array}{l}\text { Slight } \\
\text { occasional }\end{array}$ & Yes \\
\hline $\begin{array}{l}\text { G.S.W. Occipital (Palestine), } \\
29 / 11 / 17 . \text { ? injury to brain }\end{array}$ & $\begin{array}{l}\text { Severe and persistent head- } \\
\text { aches, bi-temporal, cul- } \\
\text { minating at vertex }\end{array}$ & $\begin{array}{l}\text { J.eft subtemporal decom- } \\
\text { pression, } 5 / 10 / 18 \text {. } \\
\text { Moderate degree of codema }\end{array}$ & $\begin{array}{l}\text { Slight } \\
\text { occasional }\end{array}$ & Yes \\
\hline $\begin{array}{l}\text { G.S.W. Right frontal, } 3 / 10 / 18 \\
\text { No operation }\end{array}$ & $\begin{array}{l}\text { Apathetic and listless. Con- } \\
\text { tinuous headache, usually } \\
\text { very severe }\end{array}$ & $\begin{array}{l}\text { Left subtemporal decom- } \\
\text { pression, } 19 / 10 / 18 \text {. No } \\
\text { codema, bulging only }\end{array}$ & $\begin{array}{c}\text { Slight } \\
\text { occasional }\end{array}$ & Yes \\
\hline $\begin{array}{l}\text { G.S.W. Right parieto-occipi- } \\
\text { tal, with extradural hamor- } \\
\text { rhage, and with foreign body } \\
\text { remaining in right occipital } \\
\text { lobe, } 28 / 7 / 18\end{array}$ & $\begin{array}{l}\text { Constant headache, with } \\
\text { periods of vomiting. } \\
\text { "Wake up with it, and go } \\
\text { to bed with it." } \\
\text { Jacksonian fits }\end{array}$ & $\begin{array}{l}\text { Left subtemporal decom. } \\
\text { pression, } 1 / 11 / 18 \text {. } \\
\text { Marked cedems. }\end{array}$ & Slight constant & $\begin{array}{l}\text { "I feel bettel } \\
\text { for the opera } \\
\text { tion, which } \\
\text { did me a lot } \\
\text { of good." }\end{array}$ \\
\hline $\begin{array}{l}\text { G.S.W. Right parietal, pene- } \\
\text { trating, in Mesopotamia, } \\
8 / 11 / 17\end{array}$ & $\begin{array}{l}\text { Constant headache, with } \\
\text { frequent prostration }\end{array}$ & $\begin{array}{l}\text { Left subtemporal decom- } \\
\text { pression, } 7 / 11 / 18 \text {. } \\
\text { Marked œdema }\end{array}$ & $\begin{array}{l}\text { Slight } \\
\text { occasional }\end{array}$ & Yes \\
\hline $\begin{array}{c}\text { Concussion, (blown } \\
14 / 8 / 18\end{array}$ up), & $\begin{array}{l}\text { Constant headache, with } \\
\text { periods of prostration }\end{array}$ & $\begin{array}{l}\text { Left subtemporal docom- } \\
\text { pression, } 14 / 11 / 18 \text {. } \\
\text { Marked oodema }\end{array}$ & $\begin{array}{c}\text { Slight } \\
\text { occasional }\end{array}$ & Yes \\
\hline $\begin{array}{l}\text { G.S.W. Left mastoid, pene- } \\
\text { trating, and fracture of base } \\
\text { of skull }\end{array}$ & Constent headaches & $\begin{array}{l}\text { Right subtemporal decom- } \\
\text { pression, 22/11/18. No } \\
\text { codema, marked bulging }\end{array}$ & $\begin{array}{c}\text { Slight } \\
\text { occasional }\end{array}$ & Yes \\
\hline $\begin{array}{l}\text { G.S.W. Right parietal, non- } \\
\text { penetrating, } 9 / 9 / 18\end{array}$ & $\begin{array}{l}\text { Constant headaches, with } \\
\text { periods of severe exacerba- } \\
\text { tion }\end{array}$ & $\begin{array}{l}\text { Right subtemporal decom- } \\
\text { pression, } 7 / 12 / 18 \text {. } \\
\text { No odema, some bulging }\end{array}$ & $\begin{array}{l}\text { Slight } \\
\text { occasional }\end{array}$ & $\begin{array}{l}\text { "Yes, opera } \\
\text { tion brough; } \\
\text { great relief" }\end{array}$ \\
\hline $\begin{array}{l}\text { G.S.W. Right orbito-frontal, } \\
\text { penetrating. Date? }\end{array}$ & $\begin{array}{l}\text { Constant headaches, dull } \\
\text { mentality, with frequent } \\
\text { exacerbations }\end{array}$ & $\begin{array}{l}\text { Left subtemporal decom- } \\
\text { pression, } 19 / 12 / 18 \text {. Some } \\
\text { odema, some bulging }\end{array}$ & Occasional & $\begin{array}{l}\text { "Not so bec } \\
\text { 8 a b ef or r } \\
\text { operation" }\end{array}$ \\
\hline $\begin{array}{l}\text { G.S.W. Frontel, ponetrating, } \\
\text { Dardanelles, } 12 / 8 / 16\end{array}$ & $\begin{array}{l}\text { Headaches commenced in } \\
1917 \text {, gradually becoming } \\
\text { more severe. Weakness of } \\
\text { left leg }\end{array}$ & $\begin{array}{l}\text { Left subtemporal decom- } \\
\text { pression, } 27 / 12 / 18 \text {, with } \\
\text { marked cedems }\end{array}$ & $\begin{array}{l}\text { Slight } \\
\text { oceasional }\end{array}$ & Yes \\
\hline $\begin{array}{l}\text { G.S.W. Left fronto-parietal, } \\
\text { penetrating, } 17 / 7 / 18\end{array}$ & $\begin{array}{l}\text { Constant dull headache, } \\
\text { never free }\end{array}$ & $\begin{array}{l}\text { Left subtemporal decom- } \\
\text { presion, } 1 / 2 / 19 \text {. Marked } \\
\text { odema }\end{array}$ & $\begin{array}{l}\text { Very slight, } \\
\text { constant }\end{array}$ & Yes \\
\hline $\begin{array}{l}\text { Blown up, depressed fracture } \\
\text { left frontal, dura intact, } \\
24 / 11 / 17\end{array}$ & $\begin{array}{l}\text { Constant headaches, with } \\
\text { exacerbations }\end{array}$ & $\begin{array}{l}\text { Left gubtemporal decom- } \\
\text { pression, } 12 / 9 / 18 \text {. Some } \\
\text { (ede:na, but marked bulg- } \\
\text { ing }\end{array}$ & $\begin{array}{l}\text { Constant } \\
\text { slight, severe } \\
\text { occasionally }\end{array}$ & $\begin{array}{l}\text { "Some relief } \\
\text { but not sc } \\
\text { much as an } \\
\text { ticipated" }\end{array}$ \\
\hline $\begin{array}{l}\text { Head-injury in Mexico, } 1916 \text {. } \\
\text { Headaches and fits since, } \\
\text { aggravated by service in } \\
\text { France }\end{array}$ & $\begin{array}{l}\text { More or less constant head- } \\
\text { aches. Mild epileptiform } \\
\text { seizures }\end{array}$ & $\begin{array}{l}\text { Left subtemporal decom- } \\
\text { pression, 15/4/19. Marked } \\
\text { œdems }\end{array}$ & $\begin{array}{l}\text { Severe } \\
\text { occasional }\end{array}$ & $\begin{array}{l}\text { "Operatior } \\
\text { successful st } \\
\text { far as constan } \\
\text { headaches "Bri } \\
\text { concerned" }\end{array}$ \\
\hline
\end{tabular}




\section{GUNSHOT WOUNDS OF THE HEAD}

\section{WITH PARTICULARS AND END-RESULTS-continued.}

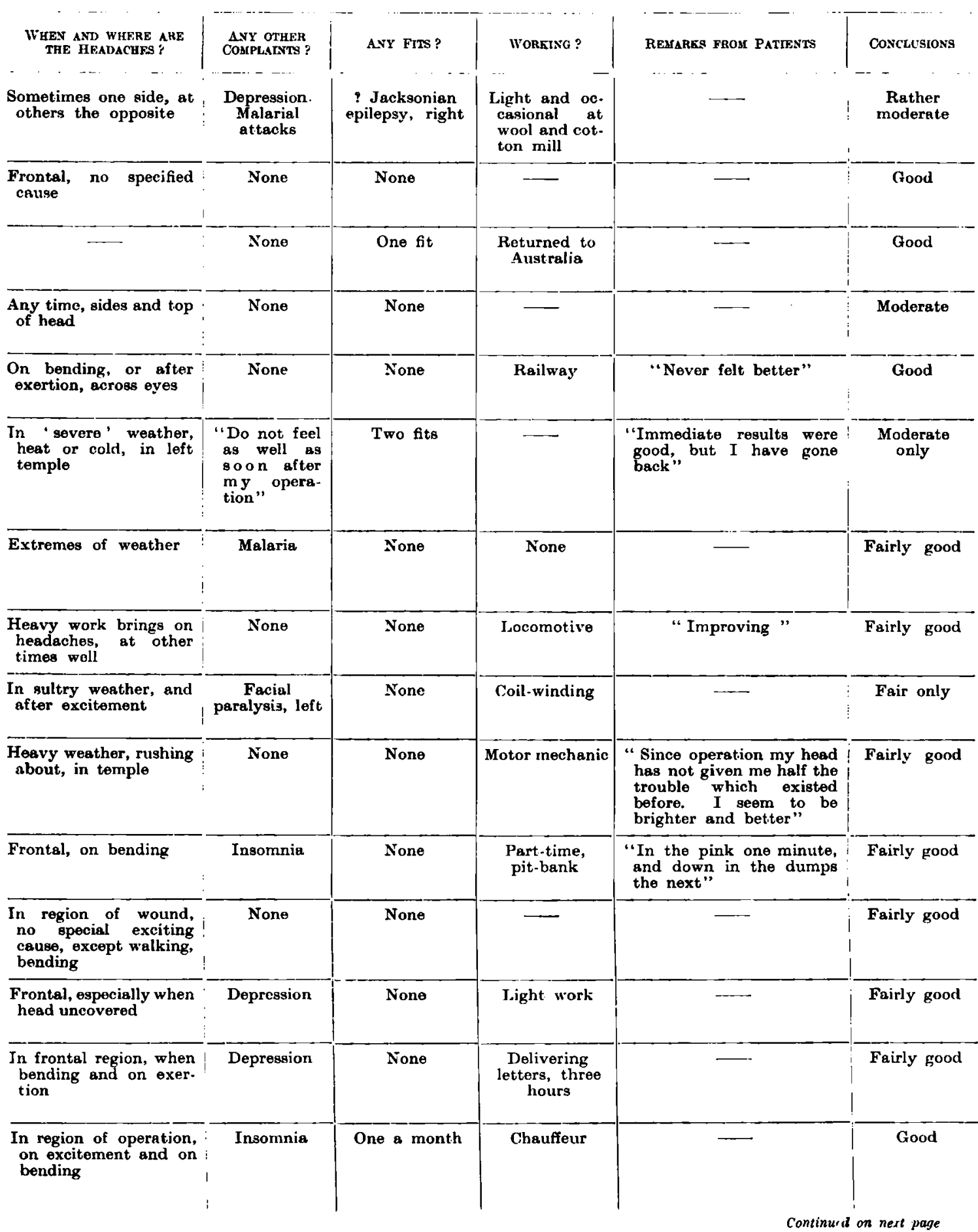


Table II.-LIST OF 40 DECOMPRESSION CASES :

\begin{tabular}{|c|c|c|c|c|}
\hline DATE AND NATURE OF INJURY & SYMPTOMS & OPERATION $\triangle$ ND DATE & $\begin{array}{c}\text { PRESENT STATE AS } \\
\text { TO HEAD iCHFS }\end{array}$ & $\begin{array}{l}\text { DID OPFRATYON } \\
\text { BRISG KELIEF? }\end{array}$ \\
\hline $\begin{array}{l}\text { G.S.W. Frontal, fissured, } \\
\text { July, 1915. Returned to } \\
\text { France, headaches commen- } \\
\text { cing May, 1918, and gradu- } \\
\text { ally getting worse }\end{array}$ & Persistent headaches & $\begin{array}{l}\text { Left subtemporal decom- } \\
\text { pression, } 24 / 3 / 19 \text {. Very } \\
\text { marked cedema }\end{array}$ & $\begin{array}{c}\text { Frequent } \\
\text { headaches, } \\
\text { though better }\end{array}$ & "Still bad a \\
\hline $\begin{array}{l}\text { G.S.W. Left frontal, pene- } \\
\text { trating, } 26 / 4 / 17\end{array}$ & $\begin{array}{l}\text { Headaches, varying, from } \\
\text { "slight' to "awful' }\end{array}$ & $\begin{array}{l}\text { Left subtemporal, } 24 / 3 / 19 \text {. } \\
\text { Some codemn and some } \\
\text { bulging }\end{array}$ & Occasional & $\longrightarrow$ \\
\hline Fractured base, $21 / 12 / 18$ & Headaches. Dull mentality & $\begin{array}{l}\text { Left subtemporal, } 1 / 5 / 19 \text {. } \\
\text { Moderate degree of cedema. }\end{array}$ & Oecasional & $-\cdots$ \\
\hline $\begin{array}{l}\text { Concussion, after mule-kick, } \\
\text { occipital, } 10 / 4 / 19\end{array}$ & $\begin{array}{l}\text { Constant headaches, dull } \\
\text { and apathetic }\end{array}$ & $\begin{array}{l}\text { Left mubtemporal, } 29 / 5 / 19 . \\
\text { Very marked œdema }\end{array}$ & $\begin{array}{c}\text { Slight } \\
\text { occessionsl }\end{array}$ & $\begin{array}{l}\text { "Still improv } \\
\text { ing wonder } \\
\text { fully : wonl } \\
\text { hardly knov } \\
\text { me for th } \\
\text { same man" }\end{array}$ \\
\hline $\begin{array}{l}\text { Epilepsy since } 7 \text { years, aggra- } \\
\text { vated by service }\end{array}$ & $\begin{array}{l}\text { Frequent fits, severe head- } \\
\text { aches, both becorning } \\
\text { worse }\end{array}$ & $\begin{array}{l}\text { Left subtemporal decom- } \\
\text { pression, 30/4/19. } \\
\text { Marked cedema }\end{array}$ & No heedaches & Yes, marked \\
\hline $\begin{array}{l}\text { G.S.W. Leit occipital, pene- } \\
\text { trating. F.B. removed from } \\
\text { right parietal region, fol- } \\
\text { lowed by hernia cerebri }\end{array}$ & $\begin{array}{l}\text { Very severe headaches, } \\
\text { general convulsions, papill- } \\
\text { odema. Streptococei in } \\
\text { cerebrospinal fluid }\end{array}$ & $\begin{array}{l}\text { Left subtemporal decom- } \\
\text { pression, } 15 / 3 / 19 \text {. Iittle } \\
\text { cedema }\end{array}$ & $\begin{array}{l}\text { Constant } \\
\text { headaches }\end{array}$ & Iittle, if any \\
\hline Blown up, concussion $26 / 1 / 15$ & $\begin{array}{l}\text { Constant headaches, with } \\
\text { numerous epileptiform fits }\end{array}$ & $\begin{array}{l}\text { Left subtemporal decom- } \\
\text { pression, } 20 / 6 / 19 \text {. } \\
\text { Moderate degree of codema }\end{array}$ & $\begin{array}{l}\text { Occasional } \\
\text { alight } \\
\text { headaches }\end{array}$ & Yes \\
\hline $\begin{array}{l}\text { G.S.W, Left parieto-occipi- } \\
\text { tal, May, } 1916\end{array}$ & $\begin{array}{l}\text { Severe headaches, dulled } \\
\text { brain, ventriculitis and } \\
\text { right hemiplegia }\end{array}$ & $\begin{array}{l}\text { Left subtemporal decom- } \\
\text { pression, 13/12/19. Much } \\
\text { bulging and little codema }\end{array}$ & $\begin{array}{c}\text { Frequent and } \\
\text { severe }\end{array}$ & - \\
\hline Concussion, March, 1919 & $\begin{array}{l}\text { Very severe headaches, apa- } \\
\text { thetic and depresser }\end{array}$ & $\begin{array}{l}\text { Left subtemporal, } 20 / 11 ! 19 . \\
\text { Very marked codema. } \\
\text { Right subtemporal, } \\
18 / 12 / 19 \text {, less codema }\end{array}$ & $\begin{array}{l}\text { Occasional, } \\
\text { slight to } \\
\text { moderate }\end{array}$ & $\begin{array}{l}\text { "Yes, and an } \\
\text { improving" }\end{array}$ \\
\hline $\begin{array}{l}\text { G.S.W. I.eft parieto-frontal, } \\
\text { penetrating, } 12 / 4 / 18\end{array}$ & $\begin{array}{l}\text { Severe and persistent hesd- } \\
\text { aches, with exacerbations, } \\
\text { dull mentality }\end{array}$ & $\begin{array}{l}\text { Left subtemporal decom- } \\
\text { pression, } 31 / 5 / 18 \text {. } \\
\text { Marked cedema }\end{array}$ & Oecasional & “Yos, muc] \\
\hline $\begin{array}{l}\text { G.S.W. Left frontal, non- } \\
\text { penetrating, } 15 / 5 / 18\end{array}$ & $\begin{array}{l}\text { Frequent headaches, dull } \\
\text { and apathetic }\end{array}$ & $\begin{array}{l}\text { Left subtemporal decom- } \\
\text { pression, } 27 / 10 / 18 \text {. Some } \\
\text { cedema, some bulging }\end{array}$ & Very slight & $\begin{array}{l}\text { "Yes, and an } \\
\text { still improv } \\
\text { ing" }\end{array}$ \\
\hline
\end{tabular}

\section{ClOSURE OR PROTECTION OF THE GAP IN THE SKULL.}

In discussing this question, two main points arise : (I) What is the object of the procedure, what is it done for? (II) What is the best method of closing or protecting the aperture in the skull?

I. The Objects of the Procedure.--These are three in number :-

1. To relieve the psychological effects produced on the patient by the mere fact that he has a hole in his skull. Can they be remedied by operation?

2. To afford some means of protection of the gap from further external injury. 


\section{GUNSHOT WOUNDS OF THE HEAD}

\section{WITH PARTICULARS AND END-RESULTS-continued.}

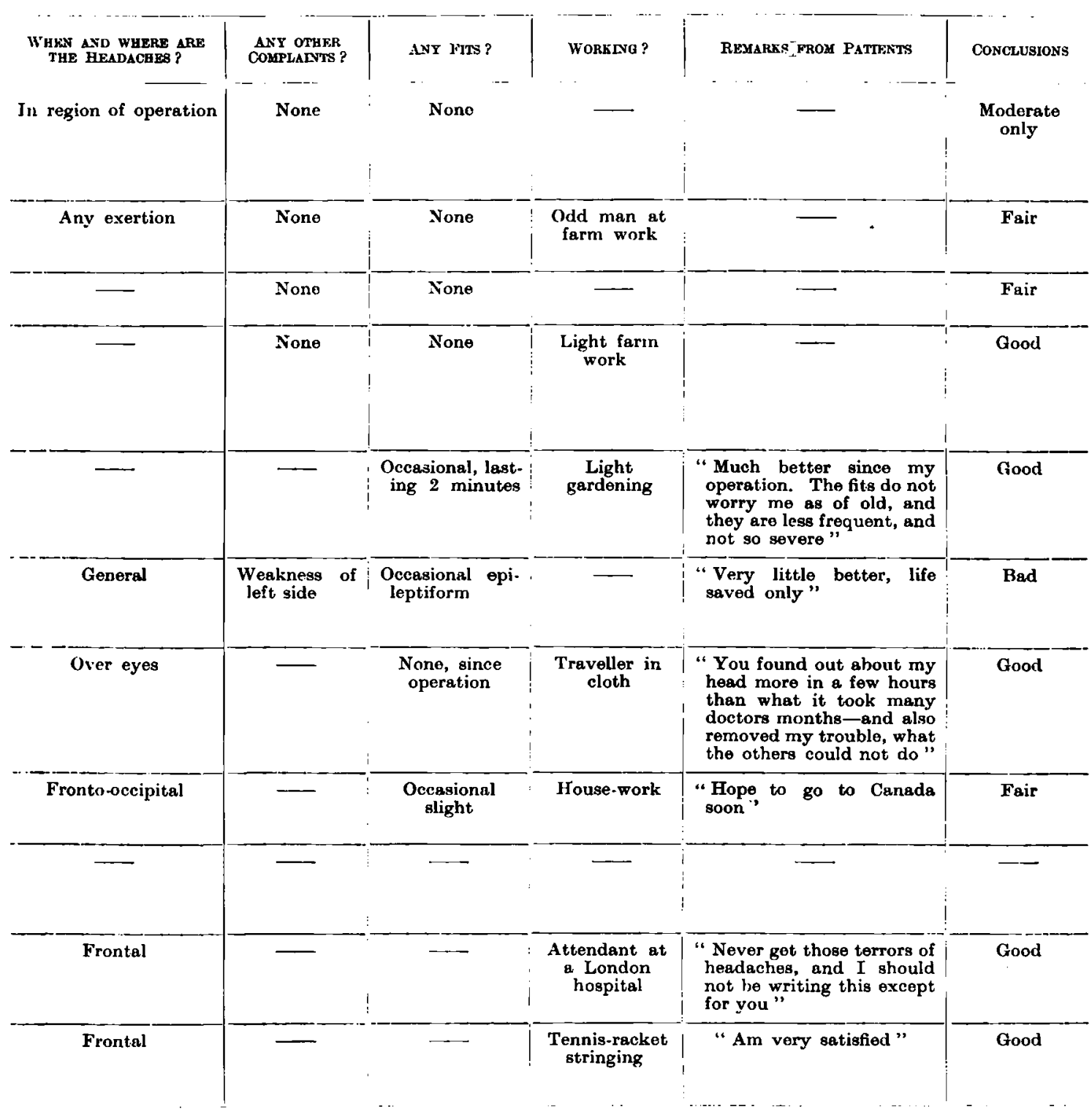

3. To relieve the patient of certain symptoms associated with, and dependent on, the injury, more especially headaches, fits, and paralyses.

1. Psychological.--The mere fact that a man has a ' hole in his skull' may bring about marked psychological effects, more especially when the defect is of considerable size, situated over the more conspicuous parts of the head, covered by a scar overlying a pulsating brain, and depressed below the surface contour of the skull-as so many of these injuries are.

The patient may feel the defect both literally and metaphorically, worrying himself about it, fingering it, and imagining all sorts of terrible after-results. Such defects render 
the patient supersensitive to observation, and he may be desirous of operation on purely psychological grounds.

Such patients form but a small group, but it is possible that an operation so planned as to render the deformity less obvious may bring about quite satisfactory results, more especially when the injury is situated in the frontal region. Silver and celluloid plates, applied in the manner described below, may benefit the patient, but all such methods present one obvious disadvantage-there is unquestionably a definite tendency for all such plates to assume, as time progresses, a degree of concavity to the surface, the result of atmospheric pressure-there is, as a rule, a shrinkage of the brain in immediate relation to the defect of the skull, and the plate gives to the external pressure, bending inwards towards the brain. This results in a concavity of the plate, and frustrates the object desired. Bone-plates will be more satisfactory in this class of case, and I regard the purely psychological cases as the only indication for bone-grafts.

In other words, when the patient is influenced solely by psychological effects, the aperture may be closed in, if otherwise desirable, with a bone-graft. All other methods are liable to fail, with corresponding disappointment to the patient.

2. Protective.-When a patient with a gap in his skull suffers from nothing more than a fear of possible injury, some form of plating may be desirable to strengthen the injured region. These cases are very few in number, and $I$ do not remember more than two or three coming to me with that specific complaint. In such cases I think the double celluloid plate method will suffice, on the ground that no method, even bone-grafting, is really protective against any serious direct injury to the region, and the celluloid method is sufficiently efficacious and quite simple.

3. Symptomatic.-The more important remote effects of gunshot wounds of the head, where a defect in the skull remains, may, so far as symptoms are concerned, be divided into two groups, a major group where the injury is followed by severe, often persistent, headaches, fits, and paralyses, and a minor group where irritability, insomnia, giddiness, and nervousness are predominant. It having been stated elsewhere that closing in or protecting the gap in the skull may improve the conditions specified, it is necessary to examine the question carefully, in the endeavour to arrive at some definite conclusion as to the degree, if any, to which the patients have benefited.

Firstly, I would ask these questions : Can any of the conditions enumerated be regarded as dependent, in their incidence and progress, on the mere presence of some osseous defect? At first sight, it would appear highly improbable that any of these symptoms could be explained on this hypothesis, and that they could be remedied by closure or protection of the aperture. There is, I think, but little doubt that that is a correct representation of the case. But there are some few cases in which operation is really beneficial. There are some patients who suffer from slight infrequent headaches, who sleep badly, who suffer from very slight epileptiform or fainting attacks, who are depressed and nervous-cases, in other words, of the mildest forms of after-effect. The closure or protection of the aperture of the skull, in such cases, often brings about great benefit-though it is possible, according to my mind, that this is mainly due to the psychological effects of the operation.

In consideration of the more serious symptoms, severe headaches, etc., the headaches are due, as explained previously, to a condition of cerebral odema, for which decompression is indicated as the rational treatment-not the closure or protection of the skull defect.

The various paralyses are due to tract degeneration, and plating, etc., cannot lessen the degree and extent of the paralyses. The fits, too, are as a rule secondary to cortical scarring and degeneration, and gap protection cannot lower their incidence. Nervousness, insomnia, giddiness, etc., are not of psychological origin ; they form part of the syndrome of cerebral cedema, and are due, I think, to the soaked, sodden state of the cerebral cortex. At first sight, therefore, one would be inclined to accept the view that closure or protection of the gap in the skull could not bring about any appreciable benefit along the lines indicated. 


\section{GUNSHOT WOUNDS OF THE HEAD}

But the question is not quite so simple. Fits, for example, may be brought about by adhesion of the brain to the overlying scalp scar, and it is clear that the interposition of plates (see below) between the scalp and the bone, merely separating brain from scalp, is not infrequently beneficial, sometimes markedly so.

Again, I would lay considerable stress on Sargent's theory-that in penetrating wounds of the brain, the dura mater becomes adherent to the margins of the osseous gap, and that the brain is adherent in the immediate vicinity of the site of dural injury to the dura itself, and, in consequence, that the brain is more or less 'anchored' to the region of the scalp and bone injury. There is, under normal conditions, a certain degree of mass movement of the brain, a certain amount of give and take on the part of the brain to rapid movements of the head, and any 'anchoring' of the brain may assist in the development of fits by local irritation, in the advent and persistence of localized and general headaches by reason of the local and spreading oedema, in the development of giddiness, etc., by lowering the general cerebral stability, etc. In view of these theories, Sargent has advanced a method of plating, referred to later, which has as a definite object the freeing of the adherent dura, the 'un-anchoring' of the brain (I apologize for the use of this term), and the prevention of further adhesion in that region. It would appear, therefore, that there are some points to be advanced in favour of closure or protection of the gap in the skull from the point of view of relief of some of the remote symptoms. Acting on Sargent's theories, I have plated defects on many occasions with, on the whole, satisfactory results. Further details will be given later as to the advantages and disadvantages of this method.

Taking the question, then, as a whole, one would be inclined to conclude :-

1. That, in the event of severe headaches, with exacerbations and prostrations, cerebral adema being in most cases the causative agent, plating is useless. Decompression is required.

2. That, in the event of hemiplegia, or paralysis of corresponding magnitude, plating brings about no benefit.

3. That, in the event of severe Jacksonian fits, of epileptic or epileptiform fits, little benefit is likely to accrue from closure or protection of the gap with bone-plates or other plates.

But when the headaches are mild and inconstant, more especially when limited to the immediate vicinity of the wound, when the fits are slight, generalized and slight, or Jacksonian and slight, and when one or both of these conditions are associated with insomnia, trepidation, and giddiness, then I believe that with plating or closure of the defect, along the lines suggested by Sargent, there is a fair probability of amelioration.

The plating question has to be considered most carefully. I have seen cases which have been plated both by myself and other surgeons where, although the immediate results were satisfactory, after a few months the old troubles returned, sometimes more forcibly than previous to the plating. And I have removed the plates in some few of the cases with immediate relief of all symptoms. In these cases, where plate removal was necessitated, the patients had complained of a great feeling of weight, of oppression in the region of the wound, with vague neuralgic pains, radiating from the plate but usually centred at some part of its circumference, often in the line and distribution of some sensory scalp nerve.

In general, my present opinion on plating, of all types, so far as indications and results are concerned, is as follows :-

1. From the point of view of psychological effects, operation, closure, or protection of the aperture is of some, but limited, benefit.

2. From the point of view of protection, the operation is of considerable benefit.

3. From the point of view of symptomatic relief, the operation may be of definite value when carried out in the type of case indicated, but is disappointing in general, more especially when conducted for the relief of severe and more or less constant headache, of fit cases of the more severe type-whether generalized or Jacksonian-and of paralyses. 
II. What is the Best Methor for Closing or Protecting a Gap in the Skull ?-

The various methods that have been adopted, both previous to the war and subsequently, may be divided into two groups : (1) Autogenous bone-grafts, to close permanently the gap in the skull. (2) Plating of the defect, together with other procedures on the lines of Sargent's theories. (Fig. 107.)

1. Bone-Grafts.-I have stated previously that I do not like bone-grafts for the skull. I will admit at once that $I$ have not used this method myself, and therefore my

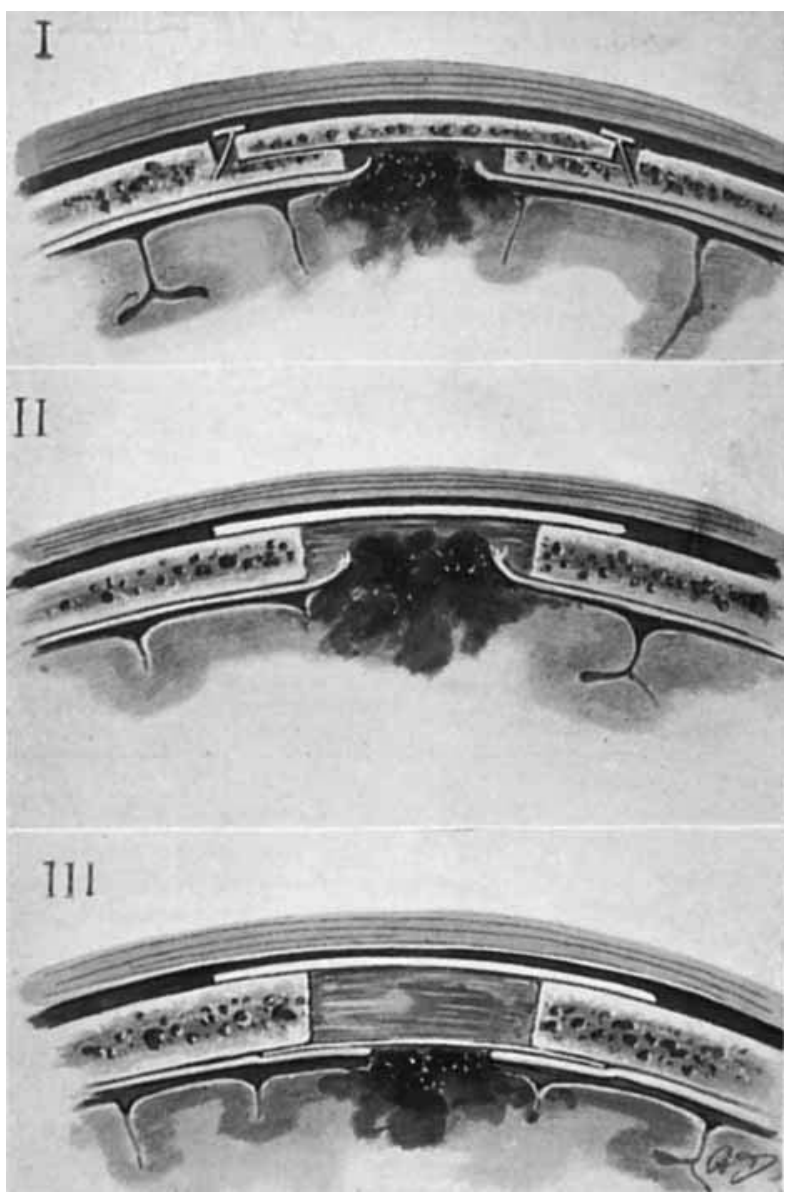

FiG. 107.-To illustrate three methods of protection or closure of defects in the skull: (i) By bone-graft; (ii) By silver plate, between scalp and bone; (iii) By two celluloid plates, an inner thin smooth plate sealp and bone; (iii) By two celluloid plates, an inner thin smooth plate
between bone and dura, an outer perforated and stronger place between scalp and bone.

opinions are not based on practical experience, but I have considered their advantages and disadvantages, their merits in a general sense, and I have seen about a dozen cases in which this method of skull protection has been carried out. I do not like the principle, nor do I like the results as seen in these few cases.

So far as principles are concerned, I have already pointed out that, so far as my personal experience goes, the benefit attained by closure or protection of the aperture in the skull by any method is very limited in practice ; that it ought not to be adopted with the idea that any considerable improvement, in respect to fits, headache, and paralyses, is likely to accrue ; and $I$ would add further that, in my opinion, the complete closure of the gap with a bonegraft which is expected permanently to close in the defect, is wrong in principle. It may be useful when the gap alone is the trouble, where the patient is perfectly well except for the hole in his skull; but such cases are relatively few in number, almost negligibly so: the great majority suffer, to a greater or less degree, from those other remote effects mentioned previously, all due to intradural changes, whether excess fluid, adhesions, or degenerations. To pay all attention to permanent closure of the gap, and to neglect the far more important intracranial changes-to dam up excess fluid, for example-is, in my opinion, entirely wrong in principle.

In further reference to bone-grafts, I have observed, in the cases that have come under my care, that the results obtained have been poor. Further, I am not convinced that the grafts will remain as bone-grafts-the skull is a poor place for bone-growth in general, and in two or three cases that $I$ have seen, the graft died, leaving a plate of dead 


\section{GUNSHOT WOUNDS OF THE HEAD}

bone exposed to the surface through sinuses discharging pus-the graft being removed subsequently with considerable difficulty.

My arguments are undoubtedly weakened by the fact that $I$ have no actual experience of bone-grafting in the skull, but $I$ believe I am right in principle and practice.

2. Plating of the Defect.Following Sargent in his theories and practice, I am accustomed to adopt the following proceduresdescribed as briefly as possible.

Material used.-Celluloid plates, two in number, the one (the outer plate) perforated, $\frac{1}{60}$ in. thick, the other (the inner plate) smooth, $\overline{2} \frac{1}{000}$ in. thick. These plates are bought in sheets and can be cut readily to the size desired.

Sterilization of the Plate.-.The fresh celluloid, cut to a convenient size and shape (Fig. 108), is washed in running water, scrubbed with soft soap and water, rinsed again in running water, then wiped over thoroughly with methylated spirit, wrapped in sterilized gauze, and put away till wanted. When required,

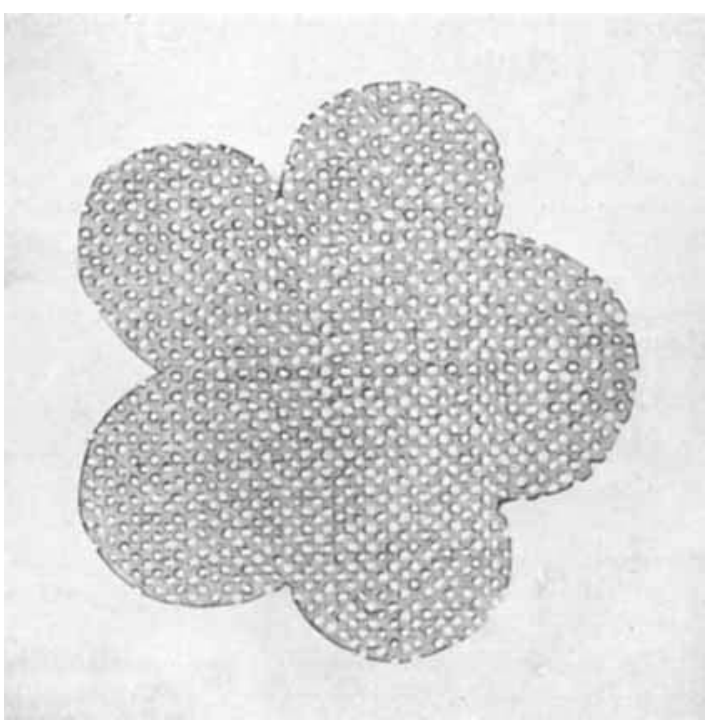

FTG. 108.-Closure or protection of apertures in the skull. The thicker outer perforated celluloid plate for insertion between scalp and bone: this plate is trimmed to some such shape as is represented in the illustration, for ready insinuation underneath the scalp.

the celluloid is placed in sterilized water, and previous to insertion is rinsed in spirit, then

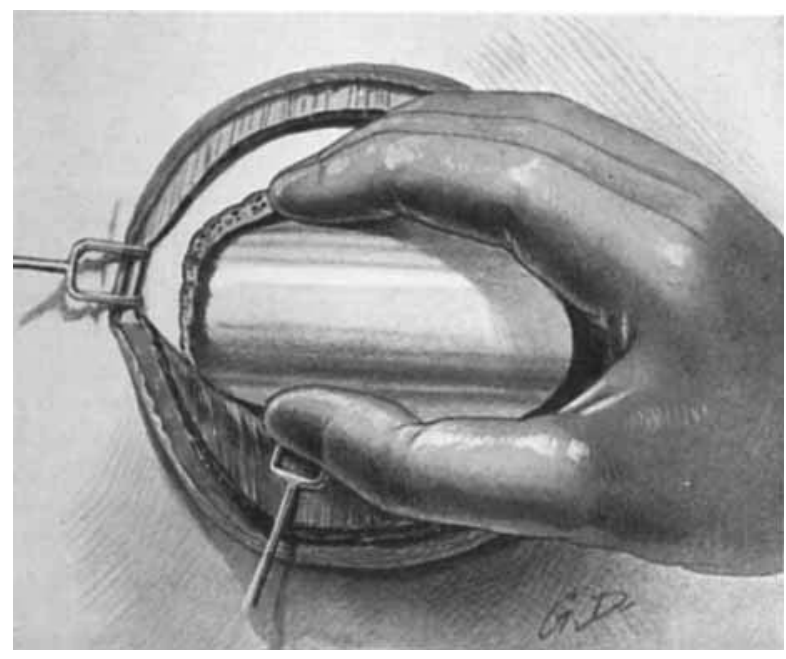

FIG. 109.-Closure or protection of apertures in the skull. The introduction of the inner thin celluloid plate; insinuation of the plate between the durs and the bone edge. washed again, after which it can be used. Immediately previous to insertion, the plate is picked up with forceps and cut to the size and shape required.

The thicker perforated plate will lie between the bone and the scalp - protective - whilst the smooth plate will be used between the dura mater and the bone, after the 'un-anchoring' of the dura mater from the margins of the aperture.

Method of Introduction.Under general anæsthesia-the head being enveloped in gauze sheet to avoid contact with the patient's skin-a flap is turned down, the whole thickness of the scalp, completely exposing the defect in the skull. This scalp incision lies one-eighth to threequarters of an inch distal to the margins of the aperture in the bone. Some part of the scalp-flap may be merely scar-tissue, adherent to the tissue immediately underlying the gap, and great care must be taken, when turning down the 
scalp-flap, to avoid button-holing the flap. All surface tissue must be included in the scalp-flap by clean dissection-even at the expense of the underlying dura, torn dura, or scar-tissue-this should be avoided whenever possible. Bleeding is controlled with the scalp tourniquet, or by means of hæmostatic forceps.

Insertion of the Inner Plale.-The pericranium is incised with a fresh scalpel, about half an inch distal to the margin of the gap, and stripped with Farabeuf's raspatory to the margin of the aperture. There it becomes adherent to the edge of the bone, to which also the dura mater is adherent in the case of a penetrating wound. With the raspatory insinuated around and beneath the osseous deficiency, the dura mater and pericranial fringe are detached from the margins of the gap, after which a flat periosteal elevator is inserted so as to strip the dura from the overlying bone for a distance of not less than one inch throughout the whole circumference of the gap. This being completed, the ragged tissue in the centre of the field is dissected away with a sharp scalpel, leaving a surface as smooth as possible, without cutting into the surface of the cortex exposed. It is important in every case to avoid injury to cortical vessels, venous sinuses, etc. This must be carried out with circumspection, a dry field remaining.

All is now ready for the insertion of the inner, smooth plate, between the bone and the dura mater (Fig. 109). If, however, the bone edges are ragged they should be smoothed with nibbling forceps, it being the general object to leave an oval opening in the bone-the plates are then introduced with ease. The thin celluloid is trimmed with scissors to correspond to the size and shape of the aperture, being about one-third of an inch larger in all diameters. It is bent or doubled so as to slide and be inserted beneath the bone, lying there snugly, overlapped by the margins of the gap throughout its circumference.

Insertion of the Outer Plate.--The scalp having been separated from the bone for a distance of about two inches peripheral to the margins of the gap, the thicker celluloid is trimmed with the scissors, with such snips here and there as will allow of the snug fitting of the plate to the convexity of the skull. The plate should overlap the margin of the aperture in the skull by not less than one inch, the edges of the plate being guided beneath the scalp-so as to overlie the gap and be overlapped by the scalp. When lying smoothly, the scalp-flap is replaced and anchored by many fine salmon-gut sutures, without drainage. Dressings and bandages are applied carefully, with the object of exercising an equal pressure throughout the wound area, thus avoiding the development of a hæmatoma.

Having been compelled to remove celluloid plates on some few occasions, twice for sepsis, and a few times because of recurrence of headache, etc., it is interesting to note how the two plates work. With respect to the septic cases, I would urge that if the temperature of the patient after operation suggests that possibility, and when the wound, on inspection, suggests the presence of a hæmatoma, it is wise to act promptly, turning down the flap and removing both plates. 'This is readily effected in the early stages. In one case, blood external to the outer plate was sterile, whilst the blood between the two plates grew pyogenic organisms. In the other case, nothing grew, but the hæmatoma was of considerable size, and $I$ think $I$ acted judiciously in removing both the plates.

When the plates are removed at a later date--months after the insertion-the following conditions were found. The outer plate was firmly anchored in position (being removed indeed with some difficulty) by strands of fibrous tissue, which had passed through all the small perforations of the plate, from scalp to bone and pericranium, except over the immediate region of the aperture itself, where the strands passed from the scalp into the perforations of the plate ; but when the plate was removed and looked at from the under surface it could be seen that where the outer plate had come into 'approximation' with the inner plate it was smooth, lined with an endothelial membrane, and no strands of fibrous tissue had here passed through the perforations.

The inner plate was equally interesting. It fulfilled its purpose admirably ; that is : (1) It was non-irritating, as proved by the fact that, after having been in position for some months, it could be lifted off from the surface of the brain or dura with the greatest ease, with no sign whatsoever of fibrous tissue development; and (2) It had prevented 


\section{GUNSHOT WOUNDS OF THE HEAD}

'anchoring' of the brain--that is to say, adherence of the dura mater to the margins of the aperture. This was so. The 'un-anchoring' process was complete and apparently permanent.

Disadvantages of Celluloid Plates.-

Special Disadvantages.-The inward sinking or depression of celluloid plates, seen in some cases, more especially those associated with considerable primary brain laceration, might be lessened by the utilization of an outer silver plate; but the silver plates are rather more bulky, less readily adapted to the curvature of the skull in the region of the defect, and less comfortable to the patient. Silver, gold, and aluminium plates are also inclined to yield to the atmospheric pressure and to become depressed. They could, of course, be made so thick as to obviate such secondary changes, but they then become bulky and generally uncomfortable.

General Disadvantages. - If the plating is carried out along the lines indicated, these celluloid plates are, in general, fairly satisfactory. For the relief of headaches, fits, and paralyses, they are-as are all plates-useless or harmful. Celluloid plates are readily sterilized; if harmful, they can be removed easily at an early date-with more difficulty later : this is one of the great advantages of these plates over all other methods, more especially over bone-grafts.

From the point of view of protection from further injury, many of my patients are advised to wear thin aluminium shields, covered with cloth and fastening round the head with narrow elastic. Some patients object to these shields because of the attention which is directed towards their head trouble. I point out to them that the shield should be regarded as a shield of honour.

\section{POSTSCRIPTUM.}

Since this paper was written as a careful and considered résumé of the remote effects of gunshot wounds of the head, I have been rather perturbed by some recent fatal cases. Before alluding to these disturbing factors, it should be noted that, of 775 fully-recorded cases, 50 died ( 6.5 per cent). Death occurred, on an average, nine weeks from the date of the primary injury. With one exception, where death resulted from tetanus, the fatal termination was due to meningo-encephalitis. In no case did the autopsy reveal a localized abscess - that is to say, an abscess with well-defined boundary ; the abscess, if present, was often loculated and of considerable size, spreading towards the surface of the brain or involving the ventricles.

In 19 of these fatal cases (38 per cent) foreign bodies were present, too deeply situated for removal, and in 22 (44 per cent) the conditions were complicated by the presence of a hernia of the cerebrum or cerebellum. In 12 cases (24 per cent) the lesion was situated in the occipito-cerebellar region.

It would appear probable that, in the 19 cases where foreign bodies were present, the foreign body in itself was not responsible for the death of the patient-42 cases are discussed elsewhere in this article with foreign bodies remaining in the brain, some in the most inaccessible positions, who are alive and well, and 58 per cent of whom are at work of some description. It is noteworthy also that, although 22 cases died with hernia cerebri, yet 35 cases recovered, 30 per cent being at work at the present time.

Again, the fatal termination of 19 cases with foreign bodies retained must in no sense be taken as an argument for more radical early efforts at removal of a foreign body. From a general survey of such cases $I$ think it is clear that the surgeons in France did not err on the side of leniency in their attempts at foreign body removal-whether the opposite was the case, I am unable to offer an opinion.

Although the average duration of life, from the date of injury till death occurred, was about nine weeks, one case lived eight and a half months, being discharged from hospital with a healed wound, and re-admitted two months later with breaking-down wound and hernia cerebri. This case has some bearing on the more recent perturbing cases alluded to at the beginning of this postscriptum. 
The more prolonged of the fatal cases gave warning as to their general unsatisfactory condition by (1) persistent headaches, (2) bouts of vomiting, (3) great depression and irritability, and (4) steady emaciation. In some cases the conditions were diagnosed long before death by means of lumbar puncture, and, in the event of positive result, more energetic treatment was at once carried out-repeated lumbar puncture, subtemporal decompression, attempts at the removal of the foreign body, drainage of abscess, vaccines, etc. I was always rather afraid of lumbar puncture - the risk of spreading the infection is so obvious-but in some cases this method of treatment was carried out energetically.

Even when meningo-encephalitis is existent, recovery may still take place, as in the following case of a left temporo-oceipital penetrating gunshot wound, with numerous small metallic and osseous fragments in the underlying brain substance, violent attacks of headache, and screaming fits. Streptococei were found in the cerebrospinal fluid on all occasions when lumbar puncture was carried out. Treatment: repeated lumbar puncture and subtemporal decompression for the relief of headaches. Patient recovered and is now seeking to obtain employment. There were some other cases of similar nature.

Now, as to the perturbing factors. Within the last six months I have had under my care, or have been asked to see, four cases where old wounds had 'flared' after having been healed for three to five years-in two cases the men had been doing ordinary work for this time, with no serious disability other than periodic headaches. Then the wound 'flared' just as so many old wounds of the extremities do ; the patient rapidly became unconscious, with epileptiform fits, and died, in spite of immediate radical treatment. In three of these cases the autopsy showed meningo-encephalitis, with no foreign bodies retained, and in the fourth case, a non-penetrating wound of the frontal region, there was an old hæmorrhage in the subjacent frontal lobe, with recent extension, and death ensued from status epilepticus.

These four cases, known to me-and there are probably many others of similar nature-lead one to think of the many patients suffering from the effects of gunshot wounds of the head, many of whom have foreign bodies retained in the brain substance. What will be their subsequent history?

\section{REFERENCES.} "Rawling, "Cerebral OEdema, its Causation and Treatment", Brit. Med. Jour., 1918, May 4; also

"Warrington, "Intracranial Effusions of Inflammatory Origin ", Quart. Jour. of Med. 1913-14, vii, 93

${ }^{3}$ Foley, Amer. Jour. of Physiol.; SAchs and MALONe, Ibid., ; WeEd and M'KIBBEN, Ibid., 1921, 48,512

- Brit. Med. Jour.

3 Armstrong-Jones, Sir Robert, Practitioner, 1921, Dec.

- JaCKson and Free, Therap. Gazette, 1921, Dec. 15. 